\title{
SUBSTITUIÇÃO DE MILHO POR INGREDIENTES ALTERNATIVOS NA DIETA DE TOURINHOS CONFINADOS NA FASE DE TERMINAÇÃO
}

\section{EDUARDO MENEGUELI PEREIRA}

Dissertação apresentada à Escola Superior de Agricultura "Luiz de Queiroz" Universidade de São Paulo, para obtenção do título de Mestre em Agronomia, Área de Concentração Ciência Animal e Pastagens.

$P I R A C I C A B A$

Estado de São Paulo - Brasil

Julho - 2005 


\section{SUBSTITUIÇÃO DE MILHO POR INGREDIENTES ALTERNATIVOS NA DIETA DE TOURINHOS CONFINADOS NA FASE DE TERMINAÇÃO}

\section{EDUARDO MENEGUELI PEREIRA}

Engenheiro Agrônomo

Orientador: Prof. Dr. FLÁVIO AUGUSTO PORTELA SANTOS

Dissertação apresentada à Escola Superior de Agricultura "Luiz de Queiroz" Universidade de São Paulo, para obtenção do título de Mestre em Agronomia, Área de Concentração Ciência Animal e Pastagens.

PIR A CICABA

Estado de São Paulo - Brasil

Julho - 2005 
Dados Internacionais de Catalogação na Publicação (CIP) DIVISÃO DE BIBLIOTECA E DOCUMENTAÇÃO - ESALQ/USP

Pereira, Eduardo Menegueli

Susbtituição de milho por ingredientes alternativos na dieta de tourinhos confinados na fase de terminação / Eduardo Menegueli Pereira. - - Piracicaba, 2005.

$85 \mathrm{p}$.

Dissertação (Mestrado) - - Escola Superior de Agricultura Luiz de Queiroz, 2005.

Bibliografia.

1. Alimentação animal 2. Confinamento animal 3. Milho 4. Nutrição animal 5. Ração

6. Subproduto para animal 7. Suplemento energético para animal 8. Touro I. Título

CDD 636.2084

"Permitida a cópia total ou parcial deste documento, desde que citada a fonte - O autor" 
AOS MEUS PAIS ARMANDO E IVONE, OS GRANDES RESPONSÁVEIS PELA MINHA FORMAÇÃO, PELO AMOR E CARINHO CONSTANTES, PELA ALEGRIA, COMPREENSÃO E INCENTIVO DURANTE TODA MINHA VIDA.

DEDICO

AOS MEUS IRMÃOS QUE AMO TANTO ELIANE, EMERSON E ELISIO, AOS MEUS QUERIDOS SOBRINHOS ANA LAURA E BRUNO,

À MINHA AMIGA, COMPANHEIRA E NAMORADA POLLYANA, 


\section{AGRADECIMENTOS}

A Deus por estar sempre ao meu lado.

À Escola Superior de Agricultura "Luiz de Queiroz" e em especial ao Departamento de Zootecnia - Setor Ruminantes, pelas oportunidades.

Ao Prof. Dr. Flávio Augusto Portela Santos pela orientação, pelos ensinamentos valiosos, pela amizade, confiança e exemplo de dedicação profissional.

Ao Conselho Nacional de Desenvolvimento Científico e Tecnológico (CNPq), pela concessão de bolsa de estudo.

À Fundação de Amparo à Pesquisa do Estado de São Paulo (FAPESP) pela concessão do aporte financeiro para a condução do projeto de pesquisa.

À Ilma Agropecuária pelo fornecimento dos animais para a realização do primeiro experimento.

Aos Prof. Dr. Luiz Gustavo Nussio e Wilson Roberto de Soares Mattos pelos ensinamentos e amizade.

Ao Prof. Dr. Moacyr Corsi e ao Dr. Marco Antônio Penati por toda colaboração e confiança em minha vida acadêmica e profissional.

Aos Prof. Dr. Alexandre Vaz Pires e Ivanete Susin pelo incentivo inicial e amizade.

Aos demais professores do Departamento de Zootecnia, pelos valiosos ensinamentos transmitidos e amizade.

Aos amigos Alexandre Pedroso, Carla Nussio, Daniel de Paula Souza e Hugo Imaizumi pela amizade e colaboração na escrita deste trabalho. 
Aos amigos e colegas de curso Carolina de Almeida Carmo, Diogo Fleury Azevedo Costa, Junio César Martinez, Narson Lima, Paulo Sérgio Correia, Rafael Luiz Clarindo, Tadeu Vinhas Voltolini e Térssio Róger Ramalho pela amizade e ajuda em diversos momentos.

Ao funcionário do Departamento de Zootecnia Laureano Alves da Silva e sua família, pelo amor com que me acolheram.

Aos demais funcionários do Departamento de Zootecnia pelo apoio incondicional e pela amizade.

Aos estagiários do CPZ que estiveram sempre ao meu lado, contribuíram para a realização deste trabalho e, sobre tudo pela amizade.

A república Zona Rural que me acolheu como membro da família e proporcionou grandes momentos da minha vida.

Aos amigos Vira Latas de Marilia pela amizade, companheirismo e momentos vividos.

Às pessoas que, direta ou indiretamente, contribuíram para a realização deste trabalho. 


\section{SUMÁRIO}

Página

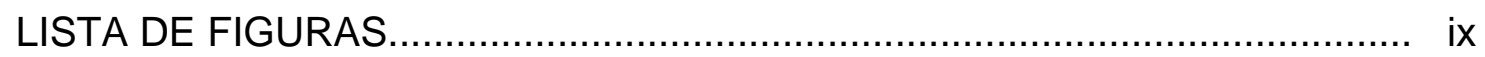

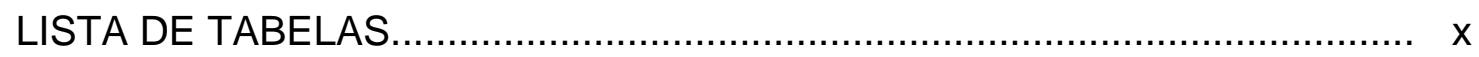

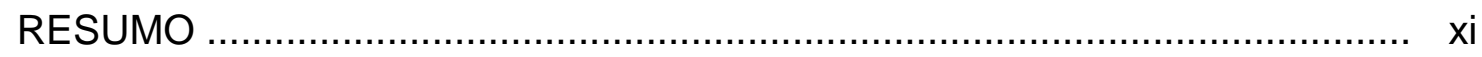

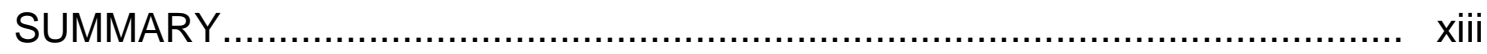

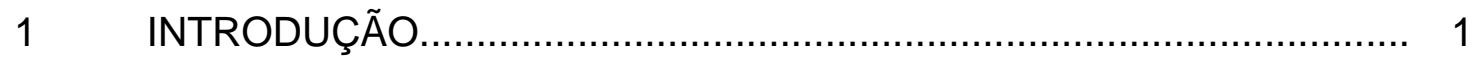

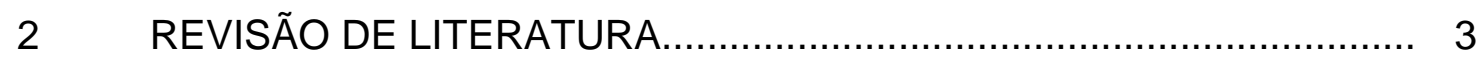

$2.1 \quad$ Fontes de energia para ruminantes........................................... 3

2.2 Amido como fonte energética para ruminantes.................................. 4

2.3 Efeito dos carboidratos não estruturais sobre o $\mathrm{pH}$ ruminal.................. 6

$2.4 \quad$ Subprodutos como fonte energética............................................... 8

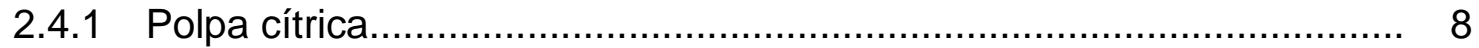

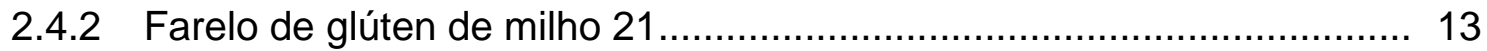

2.4.3 Farelo de Trigo.................................................................... 18

3 SUBSTITUIÇÃO DE MILHO POR POLPA CÍTRICA NA RAÇÃO DE TOURINHOS CONFINADOS NA FASE DE TERMINAÇÃO

E ESTIMATIVA DE SUA ENERGIA METABOLIZÁVEL.................... 21

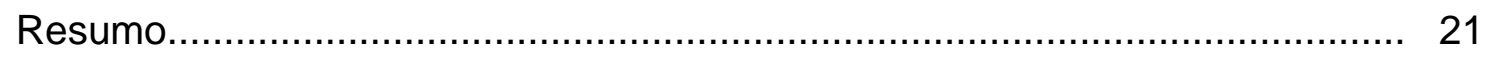

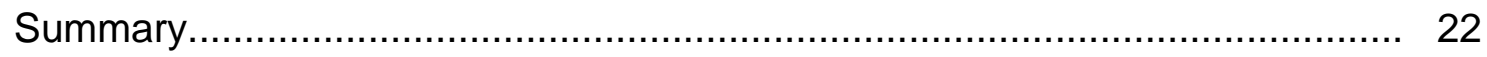

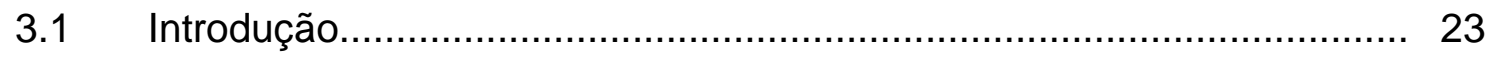

$3.2 \quad$ Material e métodos............................................................ 25

3.2.1 Animais e instalações experimentais......................................... 25 


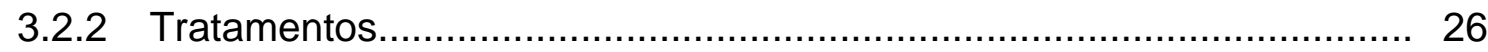

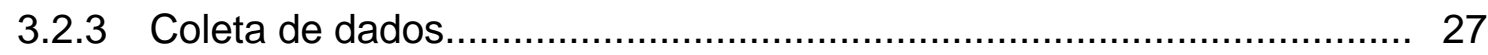

3.2.4 Análises bromatológicas...................................................... 28

3.2.5 Delineamento experimental e análise estatística.................................. 29

3.2.6 Cálculo de energia líqüida das rações e da energia metabolizável da polpa cítrica....................................................................... 31

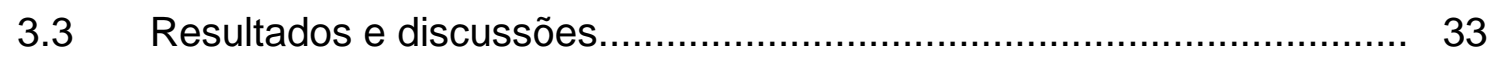

3.3.1 Composição química dos ingredientes....................................... 33

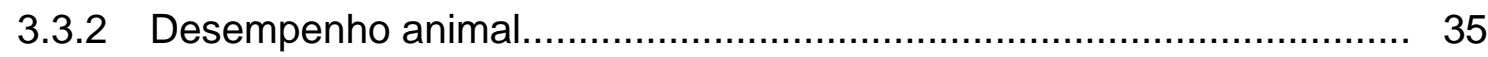

3.3.3 Espessura de gordura e rendimento de carcaça.............................. 41

3.3.4 Cálculos de energia das rações e da polpa cítrica.............................. 44

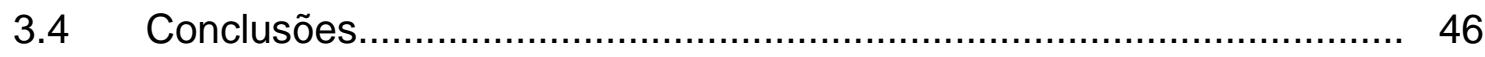

4 SUBSTITUIÇÃO DO MILHO POR FARELO DE TRIGO OU FARELO DE GLÚteN DE MILHO-21 NA RAÇÃO DE BOVINOS EM TERMINAÇÃO .................................................................. 47

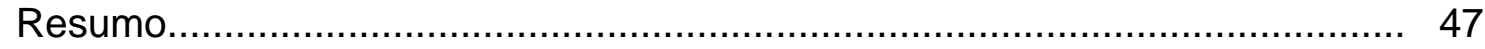

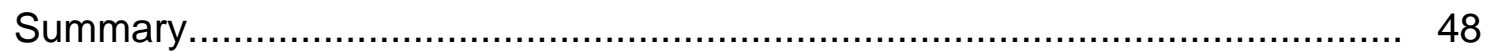

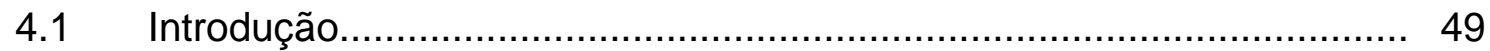

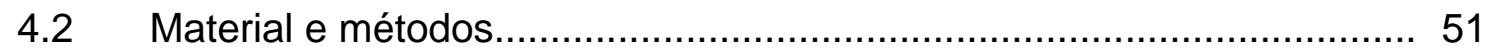

4.2.1 Animais e instalações experimentais.......................................... 51

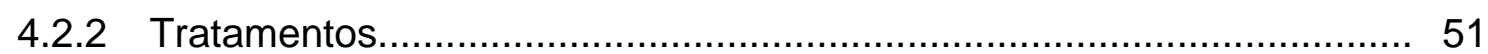

4.2.3 Coleta de dados e análises bromatológicas................................... 53

4.2.4 Delineamento experimental e análise estatística............................ 54

4.2.5 Cálculo de energia líqüida das rações............................................ 55

4.3 Resultados e discussões....................................................... 56

4.3.1 Composição química dos ingredientes........................................ 56

4.3.2 Desempenho animal.................................................................. 58

4.3.3 Cálculo de energia das rações................................................ 60

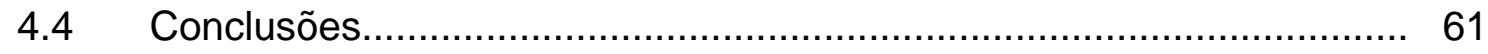

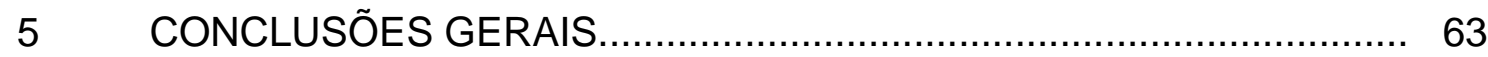


REFERÊNCIAS BIBLIOGRÁFICAS..

APÊNDICES... 


\section{LISTA DE FIGURAS}

Página

1 Variação da porcentagem da matéria seca ingerida em relação ao peso vivo durante o experimento

2 Ingestão de fibra em detergente neutro durante o experimento.

3 Deposição de gordura em tourinhos da raça Canchim.

4 Ingestão de fibra em detergente neutro durante o experimento. 


\section{LISTA DE TABELAS}

Página

1 Composição das rações experimentais...................................... 26

2 Resumo esquemático da análise de variância para espessura de gordura.

3 Resumo esquemático da análise de variância para rendimento de carcaça

4 Resumo esquemático da análise de variância para os demais parâmetros analisados. 30

5 Composição química, em porcentagem da MS, dos ingredientes. 34

6 Efeito dos tratamentos no desempenho animal............................ 35

$7 \quad$ Valor de energia líqüida das rações................................................ 44

8 Composição das rações experimentais....................................... 52

9 Resumo esquemático da análise de variância............................. 54

10 Composição química, em porcentagem da MS, dos ingredientes....... 57

11 Efeito dos tratamentos no desempenho animal............................ 58

12 Valor de energia líquida das rações................................................... 61 


\title{
SUBSTITUIÇÃO DE MILHO POR SUBPRODUTOS NA RAÇÃO DE TOURINHOS CONFINADOS NA FASE DE TERMINAÇÃO
}

\author{
Autor: EDUARDO MENEGUELI PEREIRA \\ Orientador: Prof. Dr. FLÁVIO AUGUSTO PORTELA SANTOS
}

\section{RESUMO}

Com o objetivo de avaliar o efeito da substituição do milho moído fino por ingredientes alternativos, foram realizados dois experimentos com tourinhos em terminação. As rações foram formuladas de acordo com o NRC (1996) para serem isoprotéicas e com balanço positivo de proteína degradável no rúmen e proteína metabolizável: No Experimento I foram utilizados 72 animais da raça Canchim (peso inicial $308 \mathrm{~kg}$ e idade inicial 16 meses) em um delineamento experimental em blocos casualizados com 4 tratamentos e 6 repetições. As rações continham $70 \%$ de concentrado e 30\% de silagem de cana-de-açúcar tratada com aditivo microbiano Lactobacillus buchneri 50788 (Lalsil ${ }^{\circledR}$ ). Os tratamentos consistiram de: $100 \%$ milho moído fino (M); $50 \%$ milho moído fino + 50\% polpa cítrica (P50); 25\% milho moído fino $+75 \%$ polpa cítrica (P75) e 100\% polpa cítrica $(P)$, como fontes energéticas, mais soja grão quebrada, uréia, núcleo mineral e vitamínico e monensina sódica. A ingestão de fibra em detergente neutro $(P<0,05)$, a eficiência alimentar $(P<0,05)$ e a energia líqüida de manutenção e de ganho $(P<0,10)$ foram maiores no tratamento P50 em comparação ao M. Houve redução linear $(P<0,05)$ no ganho de peso diário e na 
ingestão de matéria seca quando a polpa cítrica substituiu 75\% e 100\% do milho moído fino em comparação com 50\% de substituição. De acordo com os dados obtidos, tanto a fórmula do NRC (2001) como do NRC (1996) subestimaram o valor energético da polpa cítrica em comparação com o milho moído fino. A espessura de gordura e o rendimento de carcaça não diferiram $(P>0,05)$ entre os tratamentos. No Experimento II foram utilizados 36 tourinhos (18 Nelore e 18 Canchim), com peso inicial de $382 \mathrm{~kg}$ e 14 meses de idade. $\mathrm{O}$ delineamento experimental utilizado foi em blocos ao acaso, com os animais agrupados por raça e peso. O período experimental foi de 87 dias divididos em 3 sub-períodos. As rações continham 24\% de silagem de capim Tanzânia e 76\% de concentrado composto por polpa cítrica, farelo de soja, uréia, núcleo mineral e vitamínico, bicarbonato de sódio e monensina sódica, além de uma das fontes energéticas testadas. Os ingredientes testados foram: milho moído fino, farelo de trigo e farelo de glúten de milho-21. Em todas as rações foi mantida a proporção polpa cítrica:fonte testada de 50:50\%. A substituição de milho moído fino por farelo de glúten de milho 21 reduziu a ingestão de matéria seca, a ingestão de fibra em detergente neutro $(P<0,05)$ e o ganho de peso diário $(P<0,10)$, mas não afetou a eficiência alimentar $(P>0,05)$. A ingestão de fibra em detergente neutro aumentou $(P<0,05)$ com a substituição do milho moído fino pelo farelo de trigo, mas não alterou a ingestão de matéria seca, o ganho de peso diário e a eficiência alimentar $(P>0,05)$. Os valores observados de energia líquida de manutenção e de ganho das rações não diferiram $(P>0,05)$ entre os tratamentos, o que indica que o NRC (2001) e o NRC (1996) subestimaram o valor energético dos subprodutos utilizados em comparação com o milho moído fino. 


\title{
SUBSTITUTION OF BYPRODUCTS FOR GROUND CORN IN FEEDLOT FINISHING DIETS
}

\author{
Author: EDUARDO MENEGUELI PEREIRA \\ Adviser: Prof. Dr. FLÁVIO AUGUSTO PORTELA SANTOS
}

\section{SUMMARY}

In order to evaluate the effects of the substitution of different byproducts for ground corn, two trials were performed with finishing yearling bulls. Rations were formulated according to NRC (1996) to be isonitrogenous and have positive rumen degradable and metabolizable protein balances. In trial 1 seventy two Canchim yearling bulls (308 initial body weight and 18 months of age) were used in a randomized complete block design, with 4 treatments and 6 replications. Rations contained $70 \%$ concentrate and $30 \%$ sugarcane silage, treated with microbial additive Lactobacillus buchneri 50788 (Lalsil ${ }^{\circledR}$ ). Treatments were $100 \%$ ground corn $(\mathrm{M}), 50 \%$ ground corn $+50 \%$ dried citrus pulp (P50), 25\% ground corn $+75 \%$ dried citrus pulp (P75), and 100\% dried citrus pulp $(P)$, as energy sources. Feed efficiency $(P<0,05)$ and net energy for maintenance and gain $(P<0,10)$ were greater for $P 50$ compared to $M$. There was a linear reduction $(P<0,05)$ in daily gain and dry matter intake when citrus pulp replaced $75 \%$ and $100 \%$ of ground corn, compared with P50. According to the

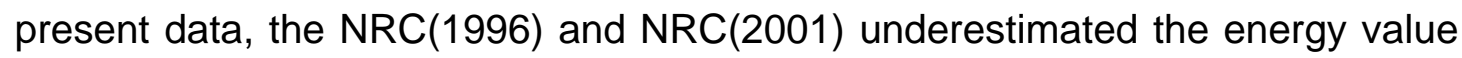
of the citrus pulp, compared to ground corn. Carcass fat depth and dressing percentage were not different $(\mathrm{P}<0,05)$ among treatments. In trial 2 thirty six 
yearling bulls (18 Nelore and 18 Canchim), averaging $382 \mathrm{~kg}$ initial live weight and 14 months of age, were used in a randomized complete block design. Animals were grouped by breed and initial live weight. Experimental period lasted 87 days, divided in 3 sub-periods. Rations contained 24\% Tanzania grass silage and $76 \%$ concentrate, composed by citrus pulp, soybean meal, urea, vitamin-mineral mix, sodium bicarbonate and sodium monensin, plus one of the energy sources tested. Ingredients tested were: fine ground corn, wheat middling and dried corn gluten feed. All rations contained a 50:50 citrus pulp:energy source ratio. Substitution of corn gluten feed for ground corn reduced dry matter intake, neutral detergent fiber intake $(P<0,05)$ and daily gain $(P<0,10)$, but did not affect feed efficiency $(P>0,05)$. Neutral detergent fiber intakes were different $(P<0,05)$ between the ground corn and wheat middling treatments, but dry matter intake, daily gain and feed efficiency were not altered $(P>0,05)$. Observed values for diets net energy of maintenance and gain did not differ $(P>0,05)$ among treatments, what indicates that NRC (2001) and NRC (1996) underestimated the byproducts energy value, compared to fine ground corn. 


\section{INTRODUÇÃO}

Nos últimos anos, a pecuária de corte brasileira vem passando por mudanças significativas. A necessidade crescente de intensificação do sistema produtivo tem aumentado a adoção de tecnologia como manejo intensivo de pastagens, suplementação de inverno, terminação em confinamento e programas de melhoramento genético. $\mathrm{O}$ uso do confinamento cresceu nesta última década cerca de $133 \%$, em conseqüência da necessidade de melhorar a eficiência de produção e a qualidade de carcaça e de carne (FNP Consultoria \& Agroinformativos, 2002).

Bovinos em crescimento e terminação apresentam elevada exigência em nutrientes, principalmente se a velocidade de ganho for alta. Nos últimos anos no Brasil, o aumento no custo de produção de volumosos, a melhoria da qualidade dos animais, a disponibilidade crescente de subprodutos e o surgimento de grandes confinamentos, têm aumentado a adoção de rações com alto teor de concentrado (Santos et al., 2004). Geralmente, esse tipo de ração contêm altos teores de carboidratos não fibrosos, principalmente amido (Gabarra, 2001). O milho é a principal fonte energética concentrada utilizada pelos confinadores nacionais. Entretanto, o preço atrativo de diversos subprodutos nas últimas safras, tem estimulado a utilização dessas fontes energéticas alternativas (Santos et al., 2004).

No Brasil, são originados grandes volumes destes subprodutos a partir do processamento de matérias primas destinadas à produção de alimentos e 
fibras. A disponibilidade da maioria destes subprodutos é regionalizada (Santos et al., 2004).

O ruminante é capaz de aproveitar alimentos impróprios para o consumo humano ou para outras espécies domésticas, eliminando assim resíduos agro-industriais como a casca de soja, a polpa cítrica e outros, que poderiam até ser indesejáveis para o meio ambiente, transformando-os em produtos de alta qualidade (carne, leite, lã etc). Isto representa uma oportunidade para redução de custo das rações e até melhoria na eficiência animal por alguns efeitos particulares existentes em alguns destes subprodutos. Entretanto, a utilização adequada destes resíduos da agroindústria ainda é limitada em algumas situações, pela escassez de informações de suas características nutricionais, desempenhos proporcionados, entre outras.

Apesar das possíveis vantagens, a adição de subprodutos às rações requer cautela, já que estes devem ser seguros, padronizados, econômicos e permitir desempenhos semelhantes aos proporcionados pelos ingredientes tradicionais.

Com base na hipótese de que, o uso estratégico de subprodutos como a polpa cítrica, o farelo de glúten de milho-21 e o farelo de trigo são fontes energéticas alternativas ao milho moído fino, dois experimentos foram conduzidos. O objetivo foi avaliar se esses subprodutos são capazes de promover desempenho semelhante ou superior ao milho, se os métodos usuais de avaliação da composição de nutrientes são eficientes em prever seus valores energéticos e se as fórmulas utilizadas pelo NRC (1996) prevêem a energia líquida das rações conforme os desempenhos proporcionados. 


\section{REVISÃO DE LITERATURA}

\subsection{Fontes de energia para ruminantes}

Em geral, grãos de cereais, especialmente o milho, representam a principal fonte de energia em rações de bovinos de corte terminados em confinamento (Huntington, 1997; Owens et al., 1997). O milho possui aproximadamente $85 \%$ de carboidratos totais, que são representados principalmente por amido (70\% da MS) (Rooney \& Pflugfelder, 1986). Isto gera implicações na fermentação ruminal e no aproveitamento de energia (Carvalho, 1998). A oferta de subprodutos provenientes da industrialização dos grãos de cereais também tem aumentado, assim como subprodutos da indústria de sucos de frutas e conserva (CONAB, 2004).

O interesse dos confinadores de bovinos de corte por fontes energéticas alternativas vem crescendo nos últimos anos, e tem como principal objetivo baixar os custos de alimentação, mantendo desempenho satisfatório. Outro benefício da inclusão de subprodutos na ração, pode ser a redução no teor de amido das rações ricas em grãos, com concomitante aumento nos teores de fibra digestível, contribuindo para melhoria do ambiente ruminal (Santos et al., 2004). 


\subsection{Amido como fonte energética para ruminantes}

O amido representa 70 a $80 \%$ da maioria dos grãos de cereais (Rooney \& Pflugfelder, 1986) e é freqüentemente a fonte primária de energia em rações para se promover altas produções em ruminantes (Theurer, 1986). É um carboidrato não estrutural e um polissacarídeo de reserva em vegetais composto por dois tipos principais de moléculas, a amilose e a amilopectina (Fahey \& Berger, 1988).

A digestibilidade do amido pode sofrer grande variação conforme o tipo de grão de cereal, o teor de amilopectina e de amilose, a camada externa do grânulo, a presença de uma matriz protéica revestindo o grânulo de amido e o método de processamento do grão (Rooney \& Pflugfelder, 1986; Theurer, 1986; Huntington, 1997; Owens et al., 1997).

Em ruminantes, o amido pode ser fermentado no rúmen e no intestino grosso por microorganismos e ou digerido enzimaticamente no intestino delgado. O principal local de digestão de amido é o rúmen, onde ácidos graxos voláteis (AGV) e proteína microbiana são produzidos (Theurer, 1986; Theurer, 1992; Huntington, 1997; Owens et al., 1997).

O primeiro passo no processo de fermentação ruminal do amido consiste na hidrólise deste polímero de glicose. As bactérias amilolíticas tendem a predominar no rúmen de animais recebendo rações com alto teor de amido. A degradação por estas bactérias envolve a ação da enzima extracelular $\alpha$ amilase, a qual age de forma aleatória ao longo da molécula de amido (Yokoyama \& Johnson, 1988). Após a degradação desta molécula em maltose e glicose, bactérias sacarolíticas fermentarão estes substratos rapidamente, através da via glicolítica para produzir piruvato. Este é o intermediário através do qual todos os carboidratos têm que passar antes de serem convertidos a ácidos graxos voláteis (AGV), $\mathrm{CO}_{2}$ e $\mathrm{CH}_{4}$ (Yokoyama \& Johnson, 1988). A proporção de acetato, propionato e butirato produzidos no rúmen depende do tipo de carboidrato fermentado, espécies de bactérias e ambiente ruminal 
(Fahey \& Berger, 1988). Rações ricas em amido normalmente apresentam maiores produções de propionato em relação as rações com elevado teor de carboidrato estrutural (Orskov, 1986). Entretanto, rações com o mesmo teor de amido total podem apresentar produções de propionato completamente diferentes em função da degradabilidade ruminal deste carboidrato (Theurer, 1986; Theurer, 1992; Huntington, 1997; Owens et al., 1997).

É evidente a importância dos AGV na absorção e utilização da energia. Reynolds et al. (1988b) mostraram que em vacas em lactação, recebendo uma ração com $60 \%$ de silagem de milho e $40 \%$ de concentrado, os AGV e o $\beta$ hidroxibutirato representaram 53\% da energia metabolizável ou $64 \%$ do fluxo líquido de energia pela veia porta.

Acredita-se que praticamente toda a produção de AGV seja absorvida através do rúmen, retículo e omaso, porém, uma quantidade considerável destes são metabolizados por tecidos ruminais durante a absorção. Em vacas leiteiras, aproximadamente $90 \%$ do butirato produzido no rúmen é metabolizado à $\mathrm{CO}_{2}$ e $\beta$-hidroxibutirato, uma proporção significante de acetato (30\%) pode ser metabolizado à $\mathrm{CO}_{2}$ e o propionato (3-15\%) pode também ser metabolizado à $\mathrm{CO}_{2}$ e lactato pelo tecido epitelial do rúmen (Reynolds et al., 1988ab e Reynolds et al., 1994).

Após a degradação ruminal, o amido remanescente passa para o intestino delgado onde pode ser digerido enzimaticamente através de um processo similar ao que ocorre em monogástricos. A molécula de amido é quebrada inicialmente no intestino delgado pela enzima $\alpha$-amilase pancreática produzindo um dissacarídeo, trissacarídeo e $\alpha$-dextrina ramificada. Estes oligossacarídeos são então hidrolisados pela ação final das enzimas presentes na parede intestinal. O produto final, glicose, pode então ser absorvida via transporte ativo juntamente com sódio (Gray, 1992).

O amido que escapa da fermentação ruminal e da digestão enzimática no intestino delgado pode ser fermentado no intestino grosso pela ação de microorganismos. Os AGV produzidos podem ser absorvidos e utilizados pelo 
ruminante; entretanto, a proteína microbiana sintetizada não pode ser absorvida, sendo completamente excretada nas fezes. Outro aspecto negativo é que parte do nitrogênio que poderia estar sendo reciclado de volta para o rúmen é desviado para o intestino grosso quando grandes quantidades de amido estão disponíveis para fermentação neste órgão. Isto pode ter um efeito negativo na utilização de $\mathrm{N}$ pelo ruminante (Fahey \& Berger, 1988).

\subsection{Efeito dos carboidratos não estruturais sobre o $\mathrm{pH}$ ruminal}

A presença de teores elevados de carboidratos prontamente fermentescíveis no rúmen, especialmente amido e açúcares, estimula o crescimento bacteriano e provoca aumento da taxa de produção de AGV, com conseqüente queda do $\mathrm{pH}$ ruminal (Nocek, 1997). Bactérias como Streptococcus bovis em condições de baixo $\mathrm{pH}$, passam a produzir lactato no lugar de acetato, condicionando ambiente favorável ao seu crescimento exclusivo. O lactato é dez vezes mais forte que os AGV e concorre para uma queda mais drástica no $\mathrm{pH}$ ruminal, comprometendo o crescimento de diversos microorganismos ruminais, especialmente os fermentadores de fibra (Van Soest et al., 1991).

A continuidade deste processo, pode fazer com que o $\mathrm{pH}$ atinja valores inferiores a 5,0 e nestas condições, o Streptococcus bovis perde eficiência, enquanto espécies mais tolerantes ao baixo $\mathrm{pH}$, como os Lactobacilli aumentam seu crescimento. Considerando que bactérias utilizadoras de ácido láctico, como Megaesphera elsdenii, têm crescimento limitado em pH abaixo de 5,5, o acúmulo de ácido lático é evidenciado, o que leva ao quadro de acidose ruminal (Carvalho, 1998).

Rações com 10 ou $20 \%$ de forragem foram comparadas para bovinos de corte confinados (Zinn , 1994). A ração com 10\% de volumoso resultou em menor pH ruminal $(5,65$ x 5,91), menor proporção de acetato e elevou a concentração de AGV. 
Segundo Owens et al. (1996), os mecanismos que levam à acidose são diferentes. A hidrólise do amido aumenta o suprimento de glicose ruminal, que atinge valores acima da concentração sangüínea. O excesso de glicose no rúmen eleva a produção de ácido lático via piruvato, que se acumula no rúmen e contribui decisivamente para a redução do $\mathrm{pH}$ ruminal. Este mecanismo parece plausível, pois condiciona a queda do $\mathrm{pH}$ à intensidade de fermentação e à fonte fermentada (geralmente carboidratos solúveis e amido). Esta hipótese faz sentido uma vez que a hidrólise e fermentação de pectina, embora intensa, não gera glicose, levando a uma menor redução do pH (Carvalho, 1998).

Chamberlain et al. (1993) estudaram o efeito da inclusão de carboidratos solúveis e amido em rações com silagem de gramínea para ovinos. O tratamento controle era composto de 0,85 $\mathrm{kg}$ de matéria seca (MS) de volumoso, sendo que os suplementos estudados foram fornecidos na quantidade de $0,2 \mathrm{~kg} / \mathrm{dia}$. A xilose, a frutose e o amido reduziram significativamente o $\mathrm{pH}$ ruminal médio em relação ao controle, ao passo que a sacarose promoveu redução não significativa e a lactose não alterou o pH ruminal.

O efeito de diferentes fontes de carboidratos no perfil de AGV produzidos no rúmen também foi discutido por Sniffen et al. (1992). Embora a fermentação de amido e açúcares produzam principalmente ácidos propiônico e lático, a fermentação de pectina gera ácido acético, reduzindo a intensidade da queda do pH ruminal, apesar das altas taxas de digestão (Van Soest et al., 1991). Ben-Ghedalia et al. (1989), compararam rações com alto teor de pectina e alto teor de amido, e constataram que o pH ruminal na ração com alta pectina foi 6,42 contra 6,18 . Também observaram maior relação acetato:propionato com a ração rica em pectina. Portanto, a presença de pectina nas rações como fonte de carboidrato, em substituição parcial ou total ao amido, pode ter efeitos positivos no ambiente ruminal, conforme discutido adiante. 


\subsection{Subprodutos como fonte energética}

\subsubsection{Polpa Cítrica}

A polpa cítrica (PC) é originada a partir da fabricação do suco de laranja, sendo composta de cascas, sementes e bagaço (Fegeros et al., 1995; Wing, 1982). O subproduto é obtido após duas prensagens das frutas para a extração do suco, que reduzem sua umidade a 65-75\%. Este material é posteriormente seco até atingir 90\% de MS, para então ser peletizado. Para facilitar o desprendimento da água e reduzir a natureza hidrofílica da pectina (carboidrato presente em maior quantidade), é feita a adição de hidróxido ou óxido de cálcio antes das prensagens, à taxa de 0,3 a 0,6\%, o que eleva os teores de cálcio no subproduto final. O processo de secagem também afeta o valor alimentar, uma vez que excesso de temperatura poderá indisponibilizar parte da proteína e carboidratos pela chamada reação de Maillard (Menezes Junior, 1999).

A partir da década de 90, com a redução na exportação para a Europa, a cotação do preço da PC no mercado interno caiu a valores inferiores ao do milho. Isto aumentou de forma significativa a utilização do produto no mercado nacional (Assis et al., 2001). Outro fator que torna a PC um alimento muito atrativo é que sua disponibilidade ocorre entre os meses de maio a janeiro, coincidindo com a entressafra de grãos e com a época de maior utilização de concentrados pelos produtores de leite e de gado de corte.

A PC é um alimento essencialmente energético, possui de 78 a $82 \%$ de nutrientes digestíveis totais (NDT) na MS (NRC 1996 e 2001), 6,1 a 8,1\% de proteína bruta e 23 a 25,1\% de fibra em detergente neutro (FDN) (NRC, 1996; O’Mara, 1999; Machado, 2001). Além disso, possui características diferenciadas quanto à fermentação ruminal e caracteriza-se como um produto intermediário entre volumosos e concentrados. 
A composição bromatológica e a palatabilidade da PC dependem da variedade da laranja, da inclusão de sementes e da retirada ou não de óleos essenciais. Em geral, a PC é caracterizada pela alta digestibilidade da MS, superior até a do milho laminado (Carvalho, 1995) e por possuir características energéticas de concentrado e fermentativas ruminais de volumoso (Ezequiel, 2001). Outro aspecto importante deste ingrediente é o alto teor de cálcio, que pode chegar a 3\% da MS, devido à adição de óxido ou hidróxido de cálcio, associado a um baixo teor em fósforo (0,13\% da MS; NRC, 1996). Além da necessidade da correção do teor de fósforo da ração, tem sido sugerido um aumento nos teores de micronutrientes, como zinco, cobre e selênio, que podem ter sua absorção prejudicada pelo alto teor em cálcio das rações com PC (Santos et al., 2004).

Apesar de variações ocasionadas durante o processo de secagem e por alterações da matéria prima, a composição nutricional da PC apresenta pequenas variações (Carvalho, 1998). Merece consideração especial a determinação dos valores de FDN e fibra em detergente ácido (FDA). Quando é feita a análise de FDA deste subproduto pelo método tradicional, a alta quantidade de substâncias pécticas não é totalmente dissolvida. Com isso, no resíduo que se utiliza para calcular a FDA, há boa quantidade pectina. Isto resulta em valores superestimados de FDA. Para evitar esta situação é necessária a realização de uma análise seqüencial, ou seja, a FDA deve ser determinada no resíduo da FDN.

Além de possuir alto teor de carboidratos solúveis e parede celular altamente digestível, a PC apresenta em sua composição a pectina (25\% da MS), que é um carboidrato constituído por polímeros de ácido galacturônico e que faz parte da estrutura da parede celular dos vegetais. A pectina é um carboidrato estrutural quase totalmente (90-100\%) degradável no rúmen (Nocek \& Tamminga, 1991; Stern \& Ziemer, 1993), sendo invariavelmente o carboidrato complexo de mais rápida degradação ruminal (Van Soest et al., 1991). Apesar de ser um carboidrato estrutural ela é alta e rapidamente degradada no rúmen devido à pequena concentração de lignina em sua composição. Segundo 
Menezes Junior (1999), a inclusão de PC peletizada aumentou as digestibilidades da matéria orgânica, MS, FDN e da FDA, quando substituiu $50 \%$ do milho das rações de vacas leiteiras.

Chesson \& Monro (1982) observaram taxas de degradação ruminal da pectina de 30 a 45\% por hora, com quase total degradação em 12 ou 18 horas. Sniffen (1988) encontrou valores similares de degradação entre 30 e 50\% por hora para a pectina, enquanto que para o amido de milho laminado a taxa foi menor e variou de 10 a 20\% por hora.

O'mara et al. (1999) estudaram a degradação de vários alimentos com bovinos e ovinos e concluíram que a degradabilidade ruminal da PC foi de 82,6\% para MS, 42,2\% para proteína e 69,0\% para FDN, sem diferença entre espécie animal.

A PC e o milho possuem cerca de $85 \%$ de carboidratos totais porém, a composição dos mesmos difere. O milho possui quase toda a sua fração de carboidratos na forma de amido (70\% da MS), já a PC apresenta um balanço entre FDN (25\% da MS), carboidratos solúveis (30\% da MS) e fibra solúvel em detergente neutro, basicamente pectina (30\% da MS) e isto gera implicações na fermentação ruminal e no aproveitamento de energia (Carvalho, 1998).

Pizon \& Wing (1976) estudaram o efeito da substituição do milho por PC (0\%, 33\%, 68\% e 100\%) em um ensaio de digestibilidade com novilhos de corte alimentados com rações que continham 66,7\% de concentrado. Eles observaram que o aumento da inclusão do subproduto na ração reduziu o $\mathrm{pH}$ ruminal $(6,85 ; 6,65 ; 6,61$ e 6,51) e aumentou a produção de ácido acético. Os autores relataram que o resíduo de citros estimulava a fermentação ruminal quando comparado ao milho.

Wing (1982) reportou em sua revisão que em rações com 32,7\% feno de alfafa, a inclusão de 0,10,20, 30 e 40\% de PC na matéria seca, substituindo 32,$7 ; 22,0 ; 11,2 ; 0$ e $0 \%$ de milho grão moído respectivamente, não afetou a digestibilidade da MS, da proteína e da energia para novilhos fistulados. Assim como relatado por Pizon \& Wing (1976), a PC aumentou a proporção molar de 
ácido acético, porém, neste estudo houve tendência em manter o $\mathrm{pH}$ ruminal em patamares mais elevados que nas rações com milho.

Em experimento realizado com bovinos de corte, Hentges et al. (1966) estudaram o efeito de adição de PC às rações e concluíram que quanto maior a inclusão deste subproduto na ração, maior a proporção de ácido acético em relação ao ácido propiônico no ambiente ruminal. Esta mudança foi de 1,13:1 para 4,35:1, quando a PC substituiu em 100\% o milho da ração. Schalch et al. (2001) citaram que esta maior proporção ruminal de ácido acético causada pela PC faz com que este alimento tenha uma menor chance de propiciar acidose ruminal, diferentemente do que ocorre com as fontes energéticas mais usuais, como os cereais, ricos em amido.

Carvalho (1998) estudou os efeitos do teor de amido na ração sobre a digestibilidade e o pH ruminal de novilhos Nelore. As rações continham alto teor de concentrado e bagaço de cana-de-açúcar tratado com pressão e vapor como volumoso. Os tratamentos visaram estudar a substituição de $48 \%$ do milho moído da ração pela PC. O tratamento com PC aumentou a digestibilidade da ração e apresentou melhor ambiente ruminal, apesar da queda mais rápida do pH ruminal logo após o fornecimento da ração. O autor concluiu que a substituição parcial do milho por PC apresenta boas possibilidades de minimizar os efeitos associativos negativos decorrentes de rações com alto teor de concentrado.

Foram encontrados poucos estudos sobre a substituição do milho por $\mathrm{PC}$ nas rações de bovinos de corte confinados na fase de terminação.

Vijchualta et al. (1980), substituíram o milho por PC mais $3 \%$ de farelo de soja, em rações isoprotéicas com $85 \%$ de concentrado e não observaram diferenças no GPD e na conversão alimentar de novilhos em terminação.

Sampaio et al. (1984) utilizaram oitenta e um novilhos da raça Nelore para estudar o efeito de diferentes teores de proteína e fontes de energia na ração. Foram utilizados três tratamentos com 40\% de volumoso (Capim elefante) e $60 \%$ de concentrado, que possuíam diferentes teores de PC e milho como fonte de energia (T1-PC, T2-50\% PC e 50\% milho e T3-somente milho). 
Os autores não observaram diferenças no ganho de peso, porém a conversão alimentar foi inferior na ração com PC.

Henrique et al. (1998) trabalharam com tourinhos da raça Santa Gertrudis com o objetivo de avaliar a substituição total do milho moído pela PC em rações com $80 \%$ de silagem de milho e $20 \%$ de concentrado. Segundo os autores, em rações com baixa proporção de concentrado (20\% da MS), o milho pode ser substituído totalmente pela PC, sem causar qualquer prejuízo no desempenho dos animais.

Prado et al. (2000) estudaram a substituição do milho (40\%, 60\%, 80\% e 100\%) pela PC em rações com 50\% de silagem de milho e 50\% de concentrado para bovinos mestiços (Nelore $x$ Angus) em terminação. As variáveis estudas, como ganho de peso diário (GPD), ingestão de MS (IMS), conversão alimentar, rendimento de carcaça, cobertura de gordura e área de olho de lombo não diferiram entre os tratamentos.

Henrique et al. (2004), avaliaram o efeito da substituição do milho pela PC sobre o desempenho e as características de carcaça de tourinhos Santa Gertrudis. As rações continham $20 \%$ de silagem de milho e $80 \%$ de concentrado. Os teores de PC foram 0, 25, 40 e 55\% na matéria seca da ração em substituição parcial ou total ao milho. Os autores não encontraram efeito da substituição do milho por PC sobre o GPD, a IMS, a eficiência alimentar, o rendimento de carcaça, área de olho de lombo e o peso da gordura renalpélvica-inguinal. Houve redução na espessura de gordura subcutânea sendo concluído que a PC pode compor até $55 \%$ da MS das rações e substituir na íntegra o milho moído.

Em estudo recentemente conduzido no Departamento de Zootecnia da Escola Superior de Agricultura "Luiz de Queiroz", a substituição de 50\% do milho moído (MM) por PC, em rações com 18\% de silagem de capim e $82 \%$ de concentrado, não afetou o desempenho de machos cruzados (Canchim $x$ Nelore) não castrados. Quando a PC substituiu 50\% do milho moído grosso, o 
desempenho animal foi melhor que na ração com 100\% de milho moído grosso (Ramalho, comunicação pessoal).

\subsubsection{Farelo de glúten de milho 21}

O farelo de glúten de milho 21 (FGM-21) é produzido no Brasil por quatro fábricas pertencentes a duas empresas distintas. A disponibilidade anual do produto no país é da ordem de 230 mil toneladas (Santos et al., 2004).

O FGM-21 é um subproduto do processamento do milho por via úmida, obtido através da separação e secagem das fibras de milho que são enriquecidas com a água de maceração. O processamento por via úmida iniciase com a limpeza do milho na indústria, para retirada de impurezas, palhas e outros materiais, através de peneiras e ciclones ou por sopradores pneumáticos, além de separadores magnéticos para separação de sujeiras metálicas. Em seguida, os grãos são colocados em tanques de aço inoxidável chamados de maceradores, onde recebem água sulfitada a $45-50{ }^{\circ} \mathrm{C}$, em corrente contínua. $\mathrm{O} \mathrm{SO}_{2}$ transforma-se em $\mathrm{H}_{2} \mathrm{SO}_{3}$ e promove a assepsia do processo, além de evitar a germinação e auxiliar no amolecimento dos grãos. $O$ tempo de maceração é de aproximadamente 42 horas e o milho absorve água até atingir 50\% de umidade. Após a maceração a massa restante é moída em moinhos de disco e vai para os hidrociclones para separação do germe. O material restante dos hidrociclones é composto de amido, glúten e casca, que após uma segunda moagem em moinhos de disco, resulta em uma pasta. Esta passa por uma série de sarilhos e peneiras vibratórias que recolhem as cascas, passando adiante apenas o amido e o glúten. As cascas são desaguadas por prensagem, sendo posteriormente misturadas com a água de maceração concentrada, e eventualmente com a torta de germe, dando origem ao FGM-21 (Fundação Cargill, 1980).

Este subproduto é um alimento energético com 78 a $80 \%$ de NDT, extrato etéreo de 2 a 3,9\% (NRC, 1996; Hopkins, 2002) e FDN de 36,2\% (NRC, 
1996) na matéria seca. A caracterização geral do produto indica que, em rações de bovinos, o FGM-21 por possuir de 21 a 23,8\% de proteína bruta com aproximadamente 70\% de digestibilidade (NRC, 1996; Hopkins, 2002), pode substituir grande parte da fonte de proteína proveniente do concentrado principalmente para animais de menor exigência. Bernard (1992) demonstrou serem satisfatórios os resultados encontrados com o FGM-21 em substituição ao milho e às fontes de proteínas tradicionais. Apesar disso, Santos et al. (1998) relataram que a qualidade da proteína de sub-produtos do milho é inferior a da soja, que é a fonte protéica mais utilizada no país.

Segundo Oliveros et al. (1989), por ser alimento energético rico em fibra altamente digestível, o FGM-21 pode ser um suplemento interessante para ruminantes mantidos em rações ricas em forragens. Também por apresentar estas características e conter teor de amido inferior ao dos grãos de cereais, ele pode reduzir o aparecimento de distúrbios metabólicos, como acidose, em rações com alto teor de concentrado (Muirhead, 1994).

Em trabalho realizado em Nebraska (EUA) com FGM-21 úmido em comparação com milho, Muirhead (1994) mostrou que animais que recebiam $100 \%$ de milho na ração, apresentavam pH ruminal abaixo de 6,0 por 11,4 horas, enquanto que os que recebiam 50 ou 100\% de FGM-21 úmido em substituição ao milho na ração apresentavam pH ruminal abaixo de 6,0 por 8,3 horas. Sindt et al. (2002) utilizaram 25 e 45\% de FGM-21 úmido na ração e observaram que, quanto maior a adição do subproduto, menor a digestibilidade da ração, havendo uma tendência do aumento do pH ruminal.

Carvalho (1998) postulou que o FGM-21 pode minimizar os efeitos associativos negativos decorrentes de rações com alto teor de concentrado. Fellner \& Belyea (1991) afirmaram que, devido aos altos teores de fibra digestível e baixo conteúdo de gordura e amido, o FGM-21 pode manter o pH ruminal em condições mais adequadas, otimizar a digestão da fibra e assim melhorar a digestão total da ração em relação ao milho. Firkins (1997) também relatou que quando concentrados com alto teor de amido foram substituídos por 
FGM-21, ocorreu um aumento no $\mathrm{pH}$ ruminal e, com isso, uma diminuição nos efeitos associativos negativos.

Tradicionalmente, no Brasil o FGM-21 tem sido comercializado na forma seca. Entretanto, a forma úmida do produto passou a ser comercializada a partir de 2004 por uma das empresas produtoras.

Alguns trabalhos nacionais foram realizados com o FGM-21 na forma úmida, sendo utilizado nas rações de confinamento como substituto de um concentrado constituído por milho grão e farelo de algodão. Os autores concluíram que o FGM-21 úmido apresentou valor nutritivo semelhante ao do concentrado com milho e farelo de algodão, sem alterações no GPD e na conversão alimentar. Nesses estudos observou-se que a inclusão de FGM-21 úmido até 50\% da MS da ração não limitou a IMS (Alleoni et al., 1990 e Boin et al., 1985).

Ham et al. (1995) utilizaram 200 novilhos em crescimento e depois em terminação com o objetivo de comparar o milho laminado com FGM-21 úmido em tratamentos com diferentes proporções dos ingredientes testados. No experimento de crescimento, a ração contendo 49\% de FGM-21 úmido e 50\% de feno alfafa apresentou um ganho 14\% superior e uma eficiência alimentar $11 \%$ maior quando comparado com as duas rações controle, que tinham $44 \%$ de milho laminado e $50 \%$ de feno de alfafa ou $33 \%$ de milho laminado, $33 \%$ feno de alfafa e 33\% de silagem de milho. Ao aumentar o FGM-21 úmido de 49 para 65\% na ração, o GPD e a eficiência alimentar aumentaram, visto que o consumo de MS não se alterou. Na fase de terminação não foram observadas diferenças entre a ração controle com 79\% de milho laminado em relação às rações contendo 35\% de FGM-21 úmido e 45,5\% de milho laminado ou $70 \%$ FGM-21 úmido e 12\% milho laminado. Quando compararam FGM-21 seco com o FGM-21 úmido, os autores observaram decréscimo na IMS da ração que continha FGM-21 úmido. Isto poderia ser explicado pelo maior teor de umidade da ração, pelo maior tamanho de partícula do alimento úmido (2mm), em comparação ao FGM-21 seco $(0,9 \mathrm{~mm})$. 
Sindt et al. (2000) utilizaram rações com 0, 30 e 60\% de FGM-21 úmido em substituição ao milho laminado e observaram um aumento no $\mathrm{pH}$ ruminal e fecal proporcional ao acréscimo de FGM-21 úmido, na ração de terminação de bovinos. Entretanto, os animais apresentaram um desempenho inferior quando submetidos à ração com 60\% de FGM-21 úmido.

Noventa e seis novilhas mestiças Simental x Angus foram utilizadas por Peter et al. (2000) com objetivo de estudar a utilização de vários subprodutos do milho para animais em crescimento. Também foi conduzido um experimento de digestibilidade com animais em terminação. No experimento de crescimento, os autores observaram um aumento no GPD de 29\% para os animais que recebiam o FGM-21 em comparação à ração controle, que continha fibra de milho modificada. No experimento de digestibilidade, foi observado grande diferença na digestibilidade da proteína bruta da ração controle em relação à FGM-21. Os autores concluíram que o FGM-21 é uma boa fonte energética e protéica para novilhas.

Em função de seu menor teor energético, seria de se esperar que a inclusão de FGM-21 em rações para bovinos confinados em substituição parcial ao milho, resultasse em menor desempenho animal. Santos et al. (2004) compilaram 14 trabalhos científicos publicados entre 1984 e 2004 que estudaram a substituição parcial ou total do milho por FGM-21 úmido (10 trabalhos) ou seco (4 trabalhos), para bovinos confinados na fase de terminação. Na totalidade dos trabalhos revisados, foram utilizadas rações com altos teores de concentrado, a maioria entre 70 a $98 \%$ da MS.

Dos 10 trabalhos com FGM-21 úmido, foram obtidas 20 comparações entre este subproduto e o milho. O FGM-21 úmido substituiu 22 a $63 \%$ do milho da ração e representou uma inclusão de 22 a 58,5\% da MS da ração. A IMS aumentou em 14 e diminuiu em 5 das 19 comparações com a substituição parcial do milho por FGM-21 úmido. Na média houve um aumento de 3,91\% na IMS. Apesar de inconsistente, os maiores aumentos foram observados com a inclusão 22 a 32\% de FGM-21 úmido na ração. A explicação para o efeito positivo do FGM-21 úmido na IMS, é um possível efeito benéfico da redução do 
teor de amido e concomitante aumento no teor de FDN efetiva em rações ricas em concentrado. A manutenção de um pH ruminal mais adequado (Krehbiel et al., 1995; Sindt et al., 2002) estimula a digestão de fibra e sua passagem pelo trato digestivo (Hussein \& Berger, 1995). Os riscos de acidose ruminal são menores em animais confinados recebendo uma combinação de milho e FGM21 úmido do que milho exclusivo como fonte energética em rações para ganho de peso elevado. O GPD aumentou em 14, não foi afetado em 1 e diminuiu em 5 das 20 comparações com a substituição parcial do milho por FGM-21 úmido. Na média, houve um aumento de 3,6\% no GPD nas 20 comparações. Nas 5 comparações onde o FGM-21 úmido reduziu o GPD, a inclusão deste subproduto na ração foi alta, 45\% a 58\% da MS da ração, assim como a taxa de substituição do milho, de 47 a 63\%. Em 3 dessas 5 comparações, a ingestão de MS foi reduzida pela inclusão excessiva de FGM-21 úmido na ração. O efeito positivo do FGM-21 úmido no GPD da maioria das comparações (14) pode ser explicado pela melhora do ambiente ruminal, reduzindo o risco de acidose clínica e principalmente a acidose subclínica. $O$ ambiente ruminal mais favorável estimulou a digestão de nutrientes e a IMS. A eficiência alimentar (GPD/IMS) aumentou em 11, não foi afetada em 3 e diminuiu em 6 das 20 comparações com a substituição parcial do milho por FGM-21 úmido. Na média houve um aumento de 1,26\% na eficiência alimentar nas 20 comparações. Das 6 comparações onde o FGM-21 úmido reduziu a eficiência alimentar, o GPD foi afetado negativamente em apenas 1 comparação. Nos outros 5 casos o efeito positivo na ingestão de MS foi maior que no GPD, resultando em efeito negativo na eficiência alimentar.

Em comparação com o FGM-21 seco, o subproduto úmido tem maior valor nutricional para bovinos em terminação (Firkins et al., 1985; Trenkle, 1987; Ham et al., 1995). O subproduto seco tem menor tamanho de partícula e conseqüentemente uma maior taxa de passagem. Essa rápida taxa de passagem pode reduzir a digestão da fração fibrosa do FGM-21 seco e assim resultar em menor teor energético do que o material úmido. 
Apenas 4 trabalhos científicos foram compilados por Santos et al. (2004), referentes ao período de 1984 a 2004, sobre a substituição do milho por FGM-21 seco para bovinos em terminação. A IMS e o GPD foram maiores quando o FGM-21 seco substituiu parcialmente o milho na ração. Entretanto, a eficiência alimentar foi afetada negativamente em 3 dos 4 trabalhos. É importante frisar que nos 4 trabalhos, a substituição do milho por FGM-21 seco (54 a 85\%), e a taxa de inclusão deste na ração (60 a 70\%), foram elevados, o que pode ter afetado negativamente o desempenho animal.

Trabalhos com inclusão de FGM-21 seco em teores entre 20 e 40\% da MS da ração de bovinos em terminação precisam ser conduzidos nas nossas condições para melhor avaliar esse produto em relação ao milho. Não foi encontrado nenhum trabalho na literatura revisada, que comparou a substituição do milho por FGM-21 seco em rações com PC, para bovinos em terminação.

\subsubsection{Farelo de trigo}

Da produção da farinha de trigo para consumo humano resultam subprodutos, dentre eles o farelo, o gérmen e frações de aleurona do grão. Todos estes subprodutos são adequados para a alimentação animal, porém apenas o farelo de trigo (FT) apresenta importância entre eles (Prates, 1995). Durante o processamento industrial do trigo, cerca de 70 a $75 \%$ da massa de grãos é convertida em farinha, sendo que os 25 a 30\% restantes são considerados subprodutos, comercializados principalmente na forma de FT, que tem boa disponibilidade no país (Santos et al., 2004).

O FT contém na MS, 73 a 83\% de NDT, 35\% de FDN e ao redor de 17 a 18\% de proteína bruta (NRC, 1996; Hinders, 2000). Sua proteína apresenta alta degradabilidade e o alimento como um todo apresenta alta degradabilidade inicial quando comparado com outros subprodutos (Machado, 2001). Sua fibra apresenta pequeno efeito estimulante de ruminação quando comparado com as 
forragens, visto que suas partículas são muito pequenas (Dhuyvetter et al., 1999).

Segundo Dhuyvetter et al. (1999), o FT é um alimento muito palatável e pode ser incorporado facilmente nas rações de ruminantes, desde que seja viável economicamente. Quando utilizado em grandes quantidades na ração, reduz o desempenho dos animais, por ser um alimento que possui menor valor energético que os grãos normalmente utilizados em rações de animais em terminação. Porém, por conter alto teor de fibra e níveis baixos de amido em relação aos grãos de cereais, espera-se que ele cause uma menor incidência de distúrbios metabólicos.

Pesquisas realizadas por Keith \& Donald (1991) e Dhuyvetter et al. (1999), concluíram que o FT peletizado pode substituir até 10\% dos grãos de uma ração para animais em terminação sem alterar o desempenho. Porcentagens maiores causaram decréscimo no GPD e na IMS. Um estudo parecido foi conduzido no North Dakota State University Carrington Research Extension Center com rações contendo 40\% e 60\% de FT em substituição ao milho. Nas rações com 40\% de FT em substituição ao milho o GPD diminuiu $4 \%$ e a IMS 3,5\%. Nas rações com 60\% de substituição, o GPD diminuiu 12\% e a IMS 9,25\% (Dhuyvetter et al., 1999).

Para bovinos em acabamento, Blasi et al. (1998a) afirmaram que o FT pode substituir até $5 \%$ dos grãos, ou pelo menos 50\% da forragem de rações de confinamento. Porém, Brandt et al. (1986) citados por Blasi et al. (1998b), mostraram que o FT pode substituir até 10\% dos grãos em rações de confinamento, sem que o desempenho seja comprometido.

Drouillard et al. (1999) trabalharam com 620 novilhos em crescimento, cruzados de raças britânicas, para comparar o FT com o milho laminado seco em rações com 40\% de feno de alfafa e 52,7 e 51,6\% dos ingredientes testados na MS respectivamente. Não foi observada diferença na IMS e apenas uma 
leve tendência de aumento do GPD e da eficiência alimentar para a ração com milho laminado.

Coetzer et al. (1999) utilizaram 72 novilhos Angus X Hereford com 299 $\mathrm{kg}$ de peso vivo inicial, para comparar o milho laminado com o FT. As rações continham $15 \%$ de feno de alfafa, 3,7\% de núcleo mineral, $77,3 \%$ de FT ou $68 \%$ de milho laminado mais $10 \%$ de farelo de soja. Eles observaram que a ração contendo o subproduto apresentou GPD e eficiência alimentar inferiores à ração controle.

Não foi encontrado nenhum trabalho na literatura revisada, que comparou a substituição do milho por FT em rações com PC para bovinos em terminação. 


\section{SUBSTITUIÇÃO DE MILHO POR POLPA CÍTRICA NA RAÇÃO DE TOURINHOS CONFINADOS NA FASE DE TERMINAÇÃO E ESTIMATIVA DE SUA ENERGIA METABOLIZÁVEL}

\section{Resumo}

O experimento foi conduzido no Departamento de Zootecnia da USPESALQ, com a finalidade de avaliar a substituição do milho moído fino por polpa cítrica na ração de bovinos machos não castrados, confinados na fase de terminação. Foram utilizados 72 machos não castrados da raça Canchim, com peso vivo inicial de $318 \mathrm{~kg}$ e 18 meses de idade. As rações continham 70\% de concentrado e 30\% de silagem de cana-de-açúcar tratada com o aditivo microbiano Lactobacillus buchneri 50788 (Lalsil $^{\circledR}$ ). Os tratamentos testados foram: $M=100 \%$ milho moído fino; $P 50=50 \%$ milho moído fino $+50 \%$ polpa cítrica; $\mathrm{P} 75=25 \%$ milho moído fino $+75 \%$ de polpa cítrica; $\mathrm{P} 100=100 \%$ de polpa cítrica. As rações eram adequadas em proteína degradável e proteína metabolizável (NRC, 1996) e continham além dos suplementos energéticos estudados, grãos de soja quebrados, uréia, núcleo mineral e vitamínico e monensina sódica. O delineamento utilizado foi o de blocos casualizados. Adotou-se um período de adaptação de 14 dias e período experimental de 116 dias, divididos em 4 sub-períodos de 29 dias. Foram avaliados o ganho de peso diário ( $\mathrm{kg}$ de PV/dia), a ingestão de matéria seca ( $\mathrm{kg}$ de MS/dia), eficiência alimentar (ganho de peso diário/ingestão de matéria seca), rendimento de carcaça (peso morto/peso vivo) e espessura de gordura $(\mathrm{mm})$ do músculo 
Longissimus dorsi com base na técnica de ultra-sonografia. A eficiência alimentar $(P<0,10)$ e a energia líqüida de manutenção e de ganho $(P<0,10)$ foram maiores na ração com 50\% de polpa cítrica e 50\% de milho moído fino em comparação à ração com 100\% de milho moído fino. O ganho de peso diário e a ingestão de matéria seca foram reduzidos (efeito linear, $P<0,05$ ) quando a polpa cítrica substituiu 75 e 100\% do milho moído fino em comparação com a ração do tratamento P50. Não foram observadas diferenças na espessura de gordura e no rendimento de carcaça. De acordo com os dados obtidos, tanto o NRC (2001) como o NRC (1996) subestimaram o valor energético da polpa cítrica em comparação ao milho moído fino.

\section{SUBSTITUTION OF CITRUS PULP FOR CORN IN FEEDLOT FINISHING DIETS AND METABOLIZABLE ENERGY ESTIMATES}

\section{Summary}

The trial was conducted at the Animal Sciences Department, USPESALQ, in order to evaluate the substitution of dried citrus pulp for fine ground corn in rations for yearling bulls. Rations contained $70 \%$ concentrate and $30 \%$ sugarcane silage, treated with microbial additive Lactobacillus buchneri 50788 (Lalsil $\left.^{\circledR}\right)$. Treatments were $100 \%$ ground corn (M), 50\% ground corn $+50 \%$ dried citrus pulp (P50), 25\% ground corn $+75 \%$ dried citrus pulp (P75), and 100\% dried citrus pulp $(P)$, as energy sources. Rations were adequate in rumen degradable and metabolizable protein (NRC, 1996), and contained one of the energy sources tested, plus cracked soybeans, urea, vitamin-mineral mix and sodium monensin. Seventy two Canchim yearling bulls, averaging $318 \mathrm{~kg}$ initial live weight and 18 months of age were utilized, in a randomized complete block 
design. An adaptation pre-trial period of 14 days was adopted, and experimental period lasted 116 days, divided in 4 sub-periods of 29 days each. Parameters evaluated were average daily weight gain $(\mathrm{kg} / \mathrm{d})$, dry matter intake $(\mathrm{kg} / \mathrm{d})$, feed efficiency (daily gain/dry matter intake), dressing percentage (live weight/dead weight), and carcass fat depth at the Longissimus dorsi muscle, with ultrasound technique. Feed efficiency $(P<0,10)$ and net energy for maintenance and gain $(P<0,10)$ were highest in $P 50$ compared to $M$. Daily weight gain and feed efficiency were reduced (linear effect, P<0,05) in P75 and P100, compared to P50. No differences were observed for fat depth and dressing percentage. According to experimental data, NRC (1996) and NRC (2001) underestimated the citrus pulp energy value, compared to fine ground corn.

\subsection{Introdução}

No Brasil, a safra crescente de grãos e hortifrutigranjeiros nos últimos anos, tem aumentado a disponibilidade não apenas de grãos de cereais, mas também de subprodutos passíveis de uso na alimentação de bovinos de corte. A utilização de subprodutos é uma alternativa utilizada com o objetivo de reduzir o custo da ração e conseqüentemente da arroba produzida. Alguns dos subprodutos disponíveis no Brasil que têm sido utilizados em substituição parcial ou total ao milho são: polpa cítrica (PC), farelo de trigo (FT), farelo de glúten 21 (FGM-21, Refinazil ${ }^{\circledR}$ ou Promill $\left.{ }^{\circledR}\right)$, casca de soja, dentre outros (Santos et al., 2004).

A PC é o subproduto da fabricação de suco concentrado pela indústria citrícola, sendo constituída por cascas, sementes, bagaço e frutas descartadas. A principal matéria prima é a laranja. Entretanto, de janeiro a abril algumas indústrias processam limão, que resulta em resíduo com características um pouco distintas (Abecitrus, 2004).

Em decorrência da liderança mundial na fabricação de suco concentrado, o Brasil é também líder na produção de PC. A produção nacional 
gira entre 1.150 mil toneladas, dependendo da safra (Abecitrus, 2004). Apesar disto, o produto foi, até meados de 1993, virtualmente desconhecido da pecuária nacional, uma vez que desde de o início da década de 70 , era exportado quase que integralmente para a Europa, para o emprego em rações para bovinos. Apenas a partir do início da década de 90, as cotações do preço da PC no mercado externo e interno caíram, chegando a atingir valores inferiores ao do milho. Isto fez com que a utilização do produto aumentasse consideravelmente no mercado nacional (Assis et al., 2001).

A quase totalidade da PC produzida no Brasil encontra-se no estado de São Paulo porém, devido ao preço muito competitivo às demais fontes energéticas, sua utilização tem abrangido outros estados. Nos últimos anos, tem se constituído em uma alternativa altamente competitiva em relação ao milho em rações para bovinos em confinamento (Santos et al., 2004).

Um dos pontos de destaque deste subproduto é a sua característica diferenciada quanto à fermentação ruminal, colocando-se como produto intermediário entre volumosos e concentrados. Diferentemente dos grãos de cereais como milho e sorgo, a PC não contém teores significativos de amido, porém ela é rica em açúcares (25\% da matéria seca, MS), pectina ( $25 \%$ da MS) e fibra altamente digestível (23\% da MS). A pectina é um carboidrato estrutural, constituído por polímeros de ácido galacturônico, que faz parte da estrutura da parede celular dos vegetais e é quase totalmente (90-100\%) degradável no rúmen (Nocek \& Tamminga, 1991; Stern \& Ziemer, 1993). Segundo Van Soest et al. (1991), a pectina é o carboidrato complexo de mais rápida degradação ruminal, com valores que podem variar de 30 a $50 \%$ por hora (Chesson \& Monro, 1982; Sniffen, 1988). Estes valores são bem superiores aos do amido de milho, que pode variar de 10 a 35\% por hora nas suas diversas formas de processamento (NRC, 1996).

Além das qualidades nutricionais do alimento e do volume produzido, a época de produção também é extremamente favorável. A safra de PC tem início 
em maio e termina normalmente em janeiro. Este período coincide com a entressafra de milho e com o período típico de confinamento no Brasil Central.

Apesar do Brasil ser o maior produtor de PC, com produção crescente nos últimos vinte anos, poucas são as pesquisas desenvolvidas com este subproduto na alimentação de bovinos de corte. Em rações com silagem de milho como volumoso, a substituição parcial ou total de milho por PC não afetou o desempenho de bovinos confinados (Prado et al., 2000; Henrique et al. 2004). Trabalhos de substituição de milho por PC em rações com silagem de cana de açúcar não foram encontrados na literatura.

Portanto, o objetivo deste trabalho foi avaliar a substituição parcial ou total do milho moído fino (MM) por PC em rações com 70\% de concentrado e $30 \%$ de silagem de cana-de-açúcar, para bovinos em terminação.

\subsection{Material e Métodos}

\subsubsection{Animais e instalações experimentais}

O experimento foi conduzido nas instalações do Departamento de Zootecnia da USP-ESALQ. Foram utilizados 72 machos não castrados da raça Canchim, com peso médio inicial de $318 \mathrm{~kg}$ e média de 18 meses de idade. Adotou-se período de adaptação de 14 dias e período experimental de 116 dias, divididos em 4 sub-períodos de 29 dias. Os animais foram alojados em 24 baias $(3 \times 11 \mathrm{~m}$ ) cobertas (3 animais por baia), com piso de concreto. Os animais foram everminados com produto com princípio ativo Abamectina e receberam dose injetável de complexo vitamínico ADE nos dias 0 e 60 do período experimental. 


\subsubsection{Tratamentos}

As rações continham $30 \%$ de silagem de cana de açúcar tratada com aditivo microbiano Lactobacillus buchneri 50788 (Lalsil ${ }^{\circledR}$ ) e 70\% de concentrado na MS. Comparou-se a inclusão de teores crescentes de PC em substituição ao MM (tabela 1).

Tabela 1. Composição das rações experimentais

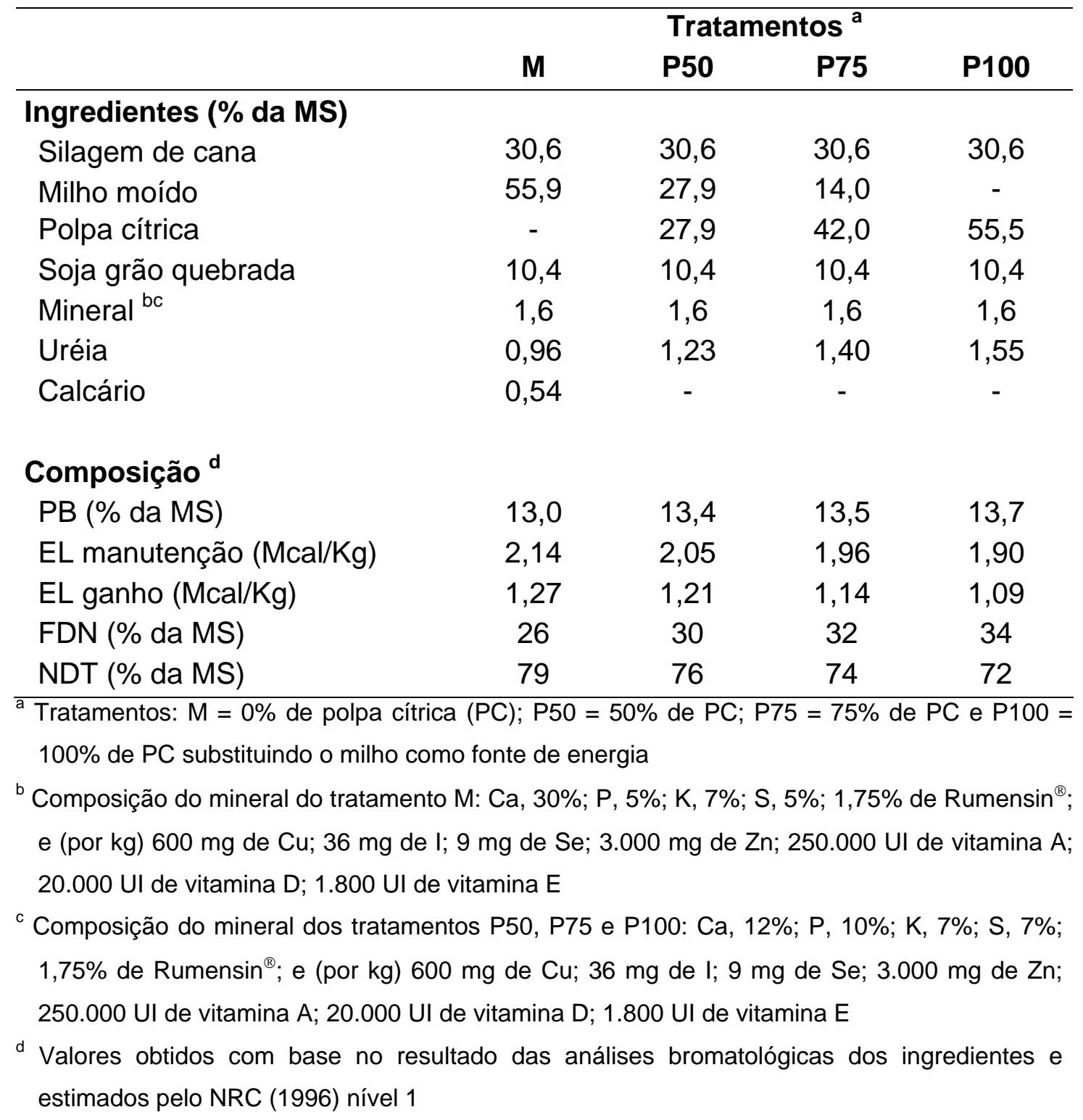


As rações foram formuladas para serem isoprotéicas e atenderem as exigências de proteína degradável no rúmen e proteína metabolizável dos animais, de acordo com o NRC (1996) nível 1. Entretanto, ao longo do experimento, foram utilizadas partidas diferentes de milho e de polpa cítrica, devido a compra parcelada desses ingredientes. A variação nos teores de proteína bruta $(\mathrm{PB})$ entre as partidas durante o período experimental, provocou uma diferença nos teores de PB das rações (Tabela 1), que foram formuladas com base na partida inicial. Apesar das rações não terem sido isoprotéicas como planejado, elas atendiam as exigências de proteína degradável e metabolizável dos animais.

O tratamento controle (M) continha apenas MM como fonte energética suplementar. A PC foi adicionada para substituir 50\% (P50), 75\% (P75) e 100\% (P100) do MM. Foram utilizados dois núcleos minerais distintos, um para o tratamento exclusivo com MM e outro para os tratamentos com PC, com o objetivo de suprir as exigências minerais dos animais, com atenção especial para o teor de cálcio e fósforo nas rações com PC.

Os concentrados foram preparados semanalmente em um misturador horizontal. Diariamente, às 18:00 horas, a ração era fornecida na forma de ração completa, com o uso de vagão misturador da marca Siltomac ${ }^{\circledR}$ equipado com balança eletrônica.

\subsubsection{Coleta de dados}

A quantidade de alimento fornecido na forma de ração completa, foi ajustada diariamente para manter no máximo $5 \%$ de sobras. As sobras eram retiradas a cada dois dias e pesadas para avaliação do consumo por baia. Em função da uniformidade entre o fornecido e as sobras (aspecto e teor de MS), assim como as quantidades pequenas de sobras obtidas, estas não foram amostradas. A ingestão de matéria seca (IMS) foi calculada como a diferença entre o fornecido e a sobra. 
Os animais foram pesados após jejum alimentar de 12 horas a cada 29 dias. Através dos dados de ganho de peso vivo diário (GPD) e da IMS, foram calculadas a eficiência alimentar dos tratamentos, que é a relação entre o GPD/IMS.

Durante as pesagens foram realizados monitoramentos in vivo do desenvolvimento do tecido adiposo subcutâneo, através da técnica de ultrasonografia (Perkins et al., 1992). O transdutor foi disposto de maneira perpendicular ao comprimento do contra filé (músculo Longissimus dorsi) entre a $12^{\underline{a}}$ e $13^{\underline{a}}$ costela. O local exato da medida da espessura de gordura subcutânea foi no terço distal da imagem do músculo. O equipamento de ultrasonografia utilizado foi o PIEMEDICAL Scanner 200 VET com imagem em tempo real, com transdutor de $3,5 \mathrm{MHz}$, com $18 \mathrm{~cm}$ e uma guia acústica necessária para o acoplamento do transdutor ao animal.

Para a avaliação do rendimento de carcaça foram abatidos 28 animais (7 animais por tratamento). Após o abate, foram mensurados os pesos de cada meia-carcaça quente para a obtenção do rendimento de carcaça, que foi calculado com base no peso vivo de abate (Tullio, 2004).

\subsubsection{Análises bromatológicas}

Sub-amostras dos ingredientes utilizados nas rações foram coletadas semanalmente e congeladas a $-10{ }^{\circ} \mathrm{C}$. Amostras da silagem foram secas a 55 ${ }^{\circ} \mathrm{C}$ para determinação do teor de MS a fim de se proceder o ajuste semanal da formulação das rações.

Para fins de análise laboratorial, as sub-amostras de alimento foram descongeladas, secas em estufas com ventilação forçada $\left(55^{\circ} \mathrm{C}\right)$ por 72 horas e compostas em amostra única de cada ingrediente (Silva, 1990). Essas foram moídas em moinhos tipo "Wiley" providos de peneiras com malha de 1 e $2 \mathrm{~mm}$ e analisadas para MS segundo Silva (1990); cinzas, extrato etéreo (EE) e proteína bruta (PB) de acordo com AOAC (1990); fibra em detergente neutro 
(FDN) e fibra em detergente ácido (FDA) de acordo com o método de Van Soest et al. (1991). As concentrações de NDT das rações foram calculadas de acordo com o NRC (2001).

Foi realizado antes do início do experimento uma mensuração da granulometria do MM, através da metodologia proposta por Yu et al. (1998), para verificar se o tamanho médio de partícula do milho estava dentro do padrão definido como fino $(1,2 \mathrm{~mm})$.

\subsubsection{Delineamento experimental e análise estatística}

Adotou-se o delineamento em blocos completos casualizados. Os animais foram distribuídos nos blocos de acordo com o peso vivo inicial. Os dados foram analisados através do procedimento MIXED do pacote estatístico SAS (1999) versão 8 para Windows. Para obtenção das médias para os tratamentos utilizou-se o método dos quadrados mínimos (LSMEANS). O quadro resumido do esquema de análise de variância utilizado está apresentado nas Tabela 2, 3 e 4.

Tabela 2. Resumo esquemático da análise de variância para espessura de gordura

\begin{tabular}{lcc}
\hline Causas de Variação & \multicolumn{2}{c}{ Graus de liberdade } \\
& Contraste M vs. P50 & $\begin{array}{c}\text { Efeito de doses } \\
\text { crescentes de PC }\end{array}$ \\
\hline Bloco & 5 & 5 \\
Tratamento & 3 & 2 \\
Resíduo & 15 & 10 \\
Total & $\mathbf{2 3}$ & $\mathbf{1 7}$ \\
\hline
\end{tabular}


Tabela 3. Resumo esquemático da análise de variância para rendimento de carcaça

\begin{tabular}{ccc}
\hline Causas de Variação & \multicolumn{2}{c}{ Graus de liberdade } \\
& Contraste M vs. P50 & $\begin{array}{c}\text { Efeito de doses } \\
\text { crescentes de PC }\end{array}$ \\
\hline Tratamento & 3 & 2 \\
Resíduo & 24 & 18 \\
Total & $\mathbf{2 7}$ & $\mathbf{2 0}$ \\
\hline
\end{tabular}

Tabela 4. Resumo esquemático da análise de variância para os demais parâmetros analisados

\begin{tabular}{lcc}
\hline Causas de Variação & \multicolumn{2}{c}{ Graus de liberdade } \\
& Contraste M vs. P50 & $\begin{array}{c}1 \\
\text { Efeito de doses } \\
\text { crescentes de PC }\end{array}$ \\
\hline Bloco & 5 & 5 \\
Tratamento & 3 & 2 \\
Resíduo A & 15 & 10 \\
Sub total & 23 & 17 \\
Período & 3 & 3 \\
Período x Tratamento & 9 & 6 \\
Resíduo B & 60 & 45 \\
Total & 95 & $\mathbf{7 1}$ \\
${ }^{1}$ Graus de liberdade associados à análise das seguintes variáveis respostas: ingestão de \\
matéria seca, ganho de peso diário, eficiência alimentar, energia líqüida de manutenção e \\
ganho e observado/esperado da energia líqüida de manutenção e ganho
\end{tabular}

Para todos os parâmetros analisados, a baia foi utilizada como unidade experimental e para acabamento de gordura apenas os dados do último período foram utilizados para análise. Apenas para a análise dos dados de rendimento de carcaça o animal foi considerado a unidade experimental. Foram realizadas análises por contraste entre os tratamentos M e P50 para verificar a existência de diferença entre o controle e o primeiro nível de substituição de $P C$, e 
análises de contraste com a finalidade de se verificar a ocorrência de efeito linear ou desvio de linearidade dentro dos tratamentos com PC (P50, P75 e P100). Durante a análise, utilizou-se o nível de $5 \%$ de probabilidade como significativo e até $10 \%$ como tendência.

Todos os dados foram testados para se verificar a distribuição normal dos erros, utilizando-se o procedimento UNIVARIATE (SAS, 1999). Os dados que apresentaram erros fora do intervalo entre \pm 3 desvios foram arbitrariamente descartados da análise estatística (Imaizumi, 2005).

\subsubsection{Cálculo de energia líqüida das rações e da energia metabolizável da polpa cítrica}

Através dos dados de IMS e GPD obtidos no experimento, foram calculados os valores de energia líquida observada das rações. Para tal, foram utilizadas as fórmulas a seguir, segundo a metodologia proposta por Zinn \& Shen (1998). O objetivo foi comparar o resultado encontrado com o previsto pelo sistema NRC (1996) nível 1. Primeiramente foram calculadas as exigências de ganho $\left(E_{g}\right)$ e de manutenção $\left(E_{m}\right)$ dos animais através das fórmulas 1 e 2, respectivamente. Calculadas as exigências energéticas relacionadas aos ganhos de peso vivo ( $\mathrm{kg} / \mathrm{dia})$ e aos pesos metabólicos $(\mathrm{kg})$ dos animais durante os quatro períodos experimentais, calculou-se então a energia líquida das rações (Mcal/kg de $M S$ ) para manutenção $\left(E L_{m}\right)$ e ganho $\left(E L_{g}\right)$ através das fórmulas 3 e 4.

$$
E_{g}=\left[0,0493 P^{0,75}\right] G P D^{1,097} ;(N R C, 1984)
$$

$E_{m}=0,077 P V^{0,75} ;($ Lofgreen \& Garrett, 1968; citados por Zinn \& Shen, 1998) 


$$
\begin{gathered}
\left.E L_{m}=\left(-b-\left(\left(b^{2}\right)-(4 a c)\right)^{0,5}\right)\right) /(2 a) ;(\text { Zinn \& Shen, 1998) } \\
a=-0,877 \text { IMS } \\
b=0,877 E_{m}+0,41 \text { IMS }+E_{g} \\
c=-0,41 E_{m}
\end{gathered}
$$

$$
E L_{g}=0,877 E L_{m}-0,41 ;(\text { Zinn \& Shen, 1998) }
$$

Onde, $E_{g}=$ exigência em energia para ganho (Mcal/dia)

$$
\begin{aligned}
& \mathrm{E}_{\mathrm{m}}=\text { exigência em energia para manutenção (Mcal/dia) } \\
& \mathrm{EL}_{\mathrm{m}}=\text { energia líqüida de manutenção (Mcal/kg de MS) } \\
& \mathrm{EL}_{\mathrm{g}}=\text { energia líqüida de ganho (Mcal/kg de MS) }
\end{aligned}
$$

Pelo fato de não se dispor de dados de consumo individual e para a realização da análise estatística, utilizou-se os dados médios de cada baia, ou seja, dados médios dos quatro sub-períodos avaliados de IMS, GPD, peso vivo e idade, para a alimentação de dados para o modelo NRC (1996) nível 1.

Foram então calculadas as relações entre concentração de energia observada:energia esperada. A energia observada foi aquela encontrada através do método acima e a esperada calculada pela metodologia do NRC (1996), que utiliza o NDT da ração para este cálculo. Os valores de análise bromatológica dos ingredientes das rações foram utilizados para o cálculo de NDT através do NRC (2001).

Também foi feito o cálculo da energia metabolizável observada da PC (EM polpa) pelo método da substituição (Zinn et al., 2002). Este método apenas pode ser utilizado quando a única alteração de fonte de energia dentro do experimento é o ingrediente testado, isto Ihe atribui maior acurácia que os levantamentos de subtração tabular. 
O método de substituição permite estimar a energia metabolizável do ingrediente testado em comparação ao ingrediente controle, mostrando se sua energia é superior ou inferior. No presente experimento o ingrediente controle utilizado foi o MM por ser um alimento com grande número de estudos na literatura, o que oferece maior confiabilidade. A energia metabolizável adotada para o MM foi de 3,19 Mcal/kg de MS. Este valor foi obtido através das fórmulas do NRC (1996), com base no NDT estimado. O NDT foi estimado conforme NRC (2001) com os dados da análise bromatológica do milho. Para realização do método de substituição, foram calculados os valores de energia metabolizável observados das rações (EMração, Mcal/kg de MS) segundo o NRC (1996) e a energia metabolizável da PC (Empolpa, Mcal/kg de MS) através das fórmulas a seguir.

$$
\begin{gathered}
E M_{\text {ração }}=\left(E L_{m}+0,696\right) / 0,91 ;(N R C, 1996) \\
E M_{\text {polpa }}=[(E M \text { ração testada }-E M \text { ração controle }) / \% \text { polpa nas rações }]+3,19 ;
\end{gathered}
$$

(Zinn et al., 2002)

\subsection{Resultados e discussão}

\subsubsection{Composição química dos ingredientes}

Os dados de composição bromatológica dos ingredientes das rações são apresentados na Tabela 5.

A silagem de cana-de-açúcar com aditivo microbiano Lactobacillus buchneri 50788 (Lalsil $^{\circledR}$ ) apresentou bom valor energético, com 61,16\% de NDT. Segundo Pedroso et al. (2004), o valor de NDT para este volumoso, deve situar-se em torno de $55-58 \%$. 
Tabela 5. Composição química, em porcentagem da MS, dos ingredientes

\begin{tabular}{lcccc}
\hline Item & $\begin{array}{c}\text { Silagem de } \\
\text { cana }\end{array}$ & $\begin{array}{c}\text { Milho moído } \\
\text { fino }\end{array}$ & $\begin{array}{c}\text { Soja grão } \\
\text { quebrada }\end{array}$ & $\begin{array}{c}\text { Polpa } \\
\text { cítrica }\end{array}$ \\
\hline Matéria seca & 29,50 & 90,04 & 93,49 & 92,62 \\
Proteína bruta & 3,42 & 9,44 & 36,40 & 7,77 \\
Extrato etéreo & 1,14 & 6,82 & 18,49 & 2,37 \\
Matéria mineral & 3,48 & 1,62 & 5,36 & 7,44 \\
FDN & 60,86 & 9,55 & 21,34 & 23,43 \\
FDA & 38,67 & 4,68 & 15,64 & 22,15 \\
NDT $^{\text {a }}$ & 61,16 & 88,29 & 100,12 & 76,62 \\
\hline${ }^{a}$ calculado segundo metodologia do NRC (2001)
\end{tabular}

O valor estimado de NDT para o MM foi de $88,29 \%$. Os teores de NDT dos alimentos nas tabelas do NRC (1996) foram obtidos principalmente de compilações de ensaios de digestibilidade (NRC, 1989; Van Soest, 1994). O NRC (1996) apresenta valores de NDT de 90\% para milho quebrado, 88\% para milho moído e 93\% para milho floculado e silagem de grão úmido. O valor inferior de NDT do milho moído em relação ao milho quebrado, não está de acordo com os dados experimentais e revisões mais recentes, que mostram valor energético maior para grãos de cereais mais processados que grãos menos processados (Huntington, 1997; Theurer et al, 1999; Zinn et al., 2002). Em estudo recente conduzido no Departamento de Zootecnia da USP/ESALQ, bovinos confinados na fase de terminação, com rações com MM, obtiveram GPD e eficiência alimentar maiores que bovinos alimentados com milho moído grosso (Ramalho, comunicação pessoal). A edição mais recente do NRC para bovinos leiteiros (NRC, 2001), calcula o NDT dos alimentos através da fórmula de Weiss (1992), assim como neste experimento, e apresenta valores de NDT de $85 \%$ para milho quebrado, $88,7 \%$ para milho moído e 91,7\% para milho floculado. O valor de NDT do milho moído fino obtido no presente estudo ficou próximo ao encontrado no NRC (2001). 
O teor de NDT estimado pela metodologia do NRC (2001) para a PC foi de $76,62 \%$, contra $82 \%$ proposto pelo NRC (1996) e 78,9\% proposto pelo NRC (2001). Estes valores sugerem que a substituição de milho por PC na ração de bovinos de corte, testada neste experimento, deveria prejudicar o desempenho animal.

\subsubsection{Desempenho animal}

Os dados de IMS e desempenho animal são apresentados na Tabela 6.

Tabela 6. Efeito dos tratamentos no desempenho animal

\begin{tabular}{|c|c|c|c|c|c|}
\hline \multirow[b]{2}{*}{ Item } & \multicolumn{4}{|c|}{ Tratamentos } & \multirow{2}{*}{ EPM } \\
\hline & M & P50 & P75 & P100 & \\
\hline Baias por tratamento & 6 & 6 & 6 & 6 & \\
\hline Peso vivo inicial, $\mathrm{kg}$ & 317,5 & 319,2 & 318,8 & 317,2 & \\
\hline Peso vivo final, $\mathrm{kg}$ & 506,0 & 526,4 & 504,9 & 493,4 & \\
\hline GPD, $\mathrm{kg} / \mathrm{dia}^{\mathrm{a}}$ & 1,59 & 1,72 & 1,55 & 1,48 & 0,074 \\
\hline IMS, kg/dia ${ }^{a}$ & 10,83 & 10,85 & 10,39 & 9,78 & 0,283 \\
\hline Ingestão de FDN, kg de MS/dia ${ }^{\mathrm{b}}$ & 2,82 & 3,24 & 3,33 & 3,33 & 0,092 \\
\hline Eficiência alimentar ${ }^{c}$ & 0,147 & 0,159 & 0,149 & 0,152 & 0,006 \\
\hline Espessura de gordura, mm & 3,89 & 4,15 & 4,15 & 4,16 & 0,136 \\
\hline Rendimento de carcaça, \% & 55,8 & 58,2 & 57,3 & 57,3 & 1,157 \\
\hline
\end{tabular}

Os valores de IMS $(9,78$ a 10,85 kg/d) obtidos no presente estudo, foram superiores ao predito pelo NRC (1996). Isto pode ser explicado pela ocorrência de crescimento compensatório. Os animais utilizados permaneceram em pastagens com restrição quantitativa e qualitativa, com ganhos de peso muito baixos ou nulo no período das secas, que antecedeu o experimento. 
O crescimento compensatório é o resultado de taxas de ganho mais elevadas do que o próprio crescimento contínuo, após períodos de restrição alimentar e de forma geral, assume-se um aumento da IMS. Segundo Lawrence \& Fowler (1997) a explicação para este aumento da IMS seria um menor enchimento ruminal por estes animais logo no início da realimentação. Aumentos de ingestão em relação ao peso vivo (PV), significa uma proporção maior de alimento sendo utilizado para ganho. Este efeito pôde ser observado nos dois períodos inicias do experimento, em que o consumo dos animais variou de 2,59 a 3,06\% da MS ingerida em relação ao PV (Figura 1), ocorrendo posteriormente uma queda abrupta.

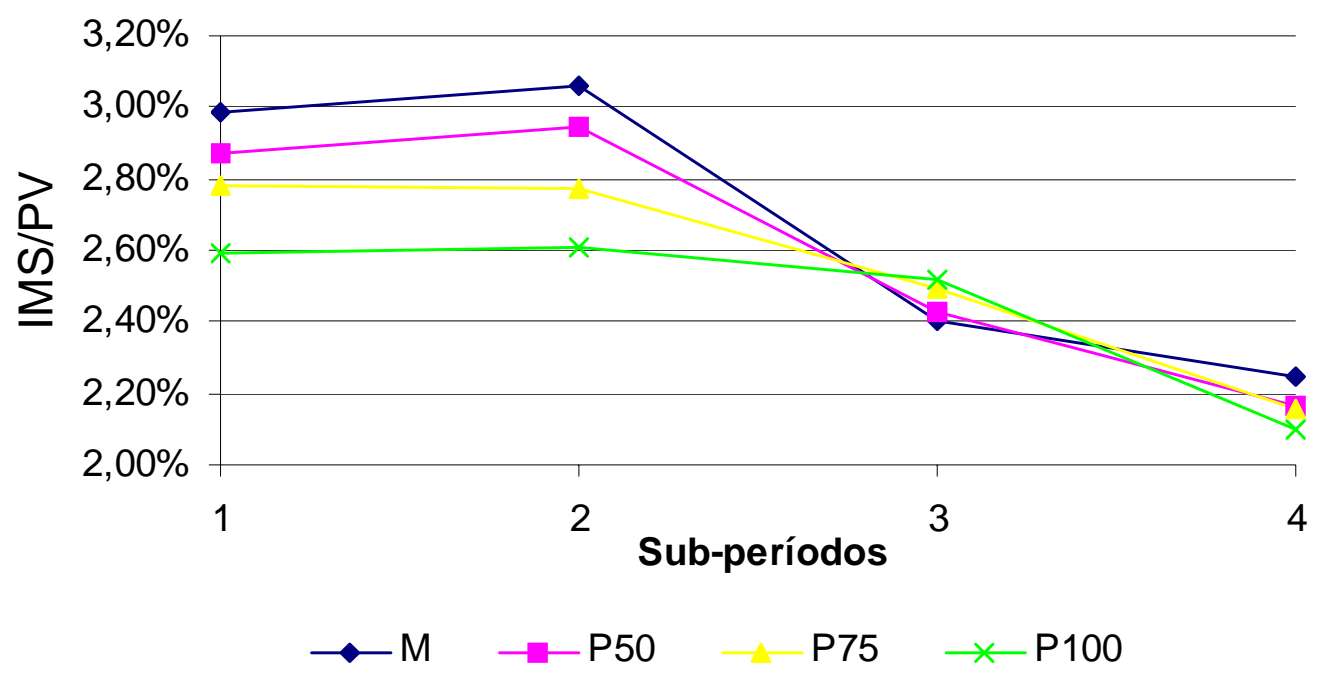

Figura 1 - Variação da porcentagem da matéria seca ingerida em relação ao peso vivo durante o experimento

O NRC (1996), apesar de discutir o efeito da restrição alimentar no consumo de alimentos, não inclui no modelo de ingestão nenhum fator para incorporar o efeito do crescimento compensatório. O modelo faz apenas uma inclusão de diminuição no requerimento de manutenção através do escore 
corporal do animal, diminuindo em $5 \%$ sua exigência cada grau de condição corporal abaixo do valor médio 5 .

A substituição de 50\% do MM por PC (M x P50) não alterou $(P>0,05)$ a IMS dos animais. Entretanto, a substituição de 75\% (P75) e 100\% (P100) do MM por $P C$ causou redução linear $(P<0,05)$ na IMS. Esta redução pode ser observada principalmente nos dois primeiros períodos experimentais (Figura 1).

O NRC (1996) estima a IMS com base na concentração de energia líquida de manutenção da ração, com ajustes para determinados fatores como teor de gordura na carcaça, grupo racial, uso de ionóforo, implante com agente anabolizante, temperatura ambiente e presença de lama. Devido ao menor valor energético da PC em comparação ao milho, sugerido nas tabelas do NRC (1996), este programa estima uma IMS maior em dietas com PC em comparação ao MM, diferente do observado no presente trabalho.

Em rações de bovinos em terminação com teores elevados de concentrado, entre 85 a 93\%, a substituição parcial de grãos de cereais como milho, por subprodutos ricos em fibra de alta digestibilidade, como FGM-21 (Refinazil $^{\circledR}$ ou Promill ${ }^{\circledR}$ ) e FT, tem causado efeitos positivos na IMS. Este aumento na IMS tem sido atribuído ao possível efeito positivo da redução do teor de amido e concomitante aumento no teor de fibra, no pH ruminal (Santos et al., 2004). O padrão de fermentação da PC difere do padrão das fontes de cereais. A PC por não conter amido e ser rica em pectina e fibra digestível, propicia padrão de fermentação mais parecido com o de forragens. Ocorre uma produção incipiente de lactato e uma relação acetato:propionato maior que na fermentação de fontes ricas em amido (Carvalho, 1998). Com base no exposto acima, poder-se-ia esperar efeito positivo da PC no ambiente ruminal e assim um efeito positivo na IMS.

Entretanto, em rações com 50\% (Prado et al., 2000) ou 20\% (Henrique et al. 2004) de silagem de milho, a substituição parcial ou total do milho moído por PC não afetou a IMS. Ramalho (comunicação pessoal) também não observou efeito positivo da PC na IMS, quando esta substituiu o milho moído fino em rações com $18 \%$ de silagem de capim para bovinos em terminação. No 
presente estudo, a PC reduziu a IMS quando substituiu o MM em mais de $50 \%$ (P75 e P100). Esta diferença de resposta da PC em relação ao relatado por Santos et al. (2004) com FGM-21 ou FT, pode ser explicada por dois fatores principais: a) no presente estudo, a ração continha $30 \%$ de forragem contra 7 a $15 \%$ na revisão de Santos et al. (2004). Neste caso, o pH ruminal provavelmente não foi crítico a ponto de responder a uma redução no teor de amido e aumento no teor de fibra; b) a inclusão de altos teores de PC na ração, pode ter resultado em teor elevado de FDN com efeito negativo na IMS (Figura 2).

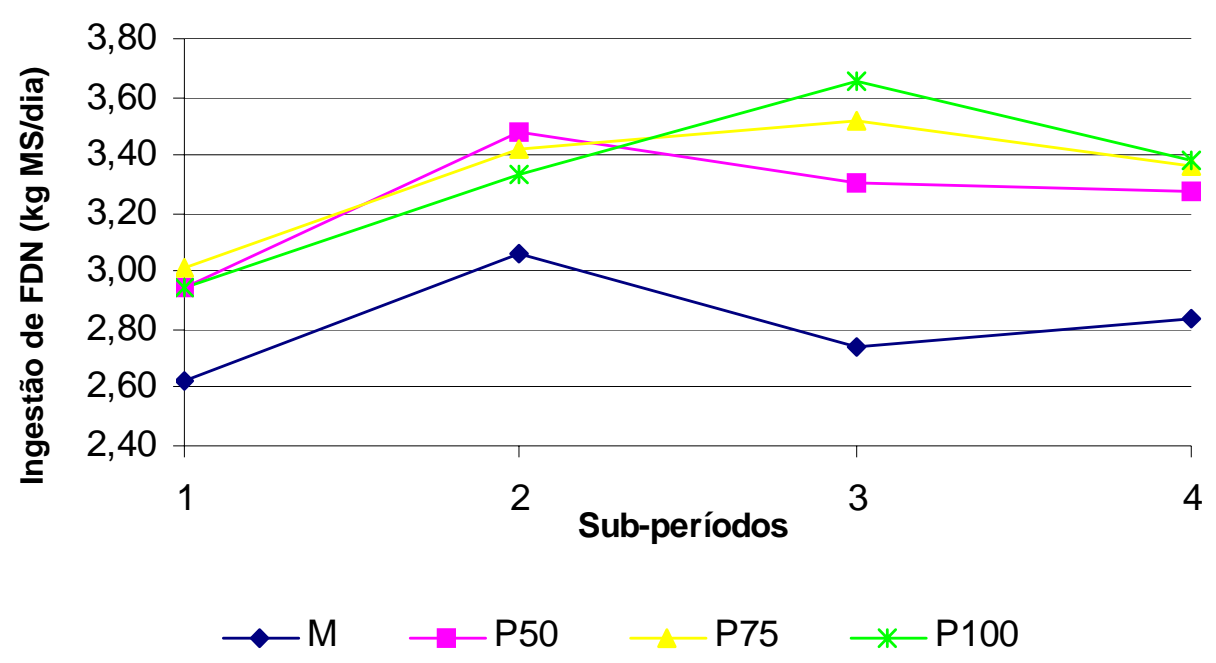

Figura 2 - Ingestão de fibra em detergente neutro durante o experimento

Staples et al. (1984) e Fellner et al. (1988), utilizaram teores acima de 50\% da MS de FGM-21 na forma úmida na ração de vacas leiteiras e observaram queda na IMS e aumento na ingestão de FDN. Eles atribuíram esta queda de consumo ao fato do aumento de FDN da ração. No presente estudo, também podemos observar que apesar da queda da IMS com a maior inclusão da PC na ração, a ingestão de FDN (Figura 2) não diferiu entre as rações com PC. 
Apesar de não afetar a IMS, a substituição de 50\% do MM por PC (M x P50) teve efeito numérico positivo no GPD $(1,59 \times 1,72 \mathrm{~kg} / \mathrm{dia}$, respectivamente). A substituição de $50 \%$ de milho moído fino por PC, em rações com 18\% de silagem de capim, não afetou o GPD dos animais, porém, a combinação de milho moído grosso e PC foi superior ao milho moído grosso como única fonte energética para bovinos em terminação (Ramalho, comunicação pessoal). Em rações com 50\% (Prado et al., 2000) e 20\% (Henrique et al., 2004) de silagem de milho, a substituição de milho por PC não afetou o GPD dos animais em terminação. Estes dados sugerem que quando em combinação com milho (50:50), o valor energético da PC é subestimado pelo NRC (1996) e NRC (2001).

$\mathrm{Na}$ discussão anterior sobre os dados de IMS, foi sugerido que a ausência de efeito positivo da PC na IMS quando 50\% do milho foi substituído por este ingrediente, poderia ser uma indicação de que o $\mathrm{pH}$ ruminal estivesse satisfatório na ração com milho. Entretanto, a questão que se coloca é como explicar o aumento numérico em GPD dos animais neste caso. Uma possível explicação seria baseada em alguns dados onde o efeito benéfico no pH ruminal, não necessariamente aumenta a IMS. A hipótese, é que tenha ocorrido uma melhora na digestibilidade da ração, com aumento no aporte de energia para o animal, sem aumento na IMS. Outra explicação seria o possível efeito benéfico na sincronização da degradação ruminal entre proteína e energia, quando se tem uma combinação de fontes de carboidratos de alta digestibilidade ruminal. No caso, amido, açúcares, pectina e fibra de alta digestibilidade ao invés da predominância de apenas uma dessas fontes. Experimentos de metabolismo que comprovem estas hipóteses não foram encontrados na literatura.

Em comparação com a ração $\mathrm{P} 50$, a substituição do $\mathrm{MM}$ por teores crescentes de PC, como nas rações P75 e P100, causou redução linear $(P<0,05)$ no GPD $(1,72 \times 1,55 \times 1,48 \mathrm{~kg} / \mathrm{d})$ dos animais. Esta redução no GPD pode ser explicada pela redução linear na IMS nessas rações $(10,85$ x 10,39 x $9,78 \mathrm{~kg} / \mathrm{d})$. 
Trabalhos clássicos da década de 70 , com rações ricas em cana-deaçúcar para bovinos, mostraram que a IMS e o GPD eram aumentados significativamente com a suplementação com pequenas doses de concentrado contendo proteína e amido não degradáveis no rúmen. Segundo Leng \& Preston (1976), o uso de cana-de-açúcar como volumoso seria limitado pelo suprimento de aminoácidos (proteína) e glicose (amido) pós-rúmen de origem alimentar e este perfil nutricional resultaria em queda na IMS. Preston et al. (1976) utilizaram doses crescentes de farelo de polidura de arroz (0,4 a 1,2 kg/cabeça/dia) para novilhos alimentados com cana-de-açúcar, melaço e uréia, e observaram um aumento linear da IMS e do GPD. Em experimento conduzido por Montepellier \& Preston (1977) foi observado o mesmo comportamento, pois a adição 0,5 kg/cabeça/dia de farelo de polidura de arroz à ração fez a IMS praticamente dobrar, quando comparado à cana-de-açúcar exclusivamente. Apesar da queda na IMS e no GPD no tratamento P100, onde o teor de amido foi muito baixo, quase nulo, os valores de IMS e GPD não foram baixos. O GPD de 1,48 kg/dia é um ganho bom para animais em terminação.

Esta questão da necessidade e da proporção adequada de amido que entra no intestino delgado e que deve ser absorvido como glicose, tem sido discutida (Nocek \& Tamminga, 1991). Trabalhos conduzidos nos últimos 20 anos com animais implantados com catéteres, para avaliação do metabolismo pós absortivo têm mostrado que os tecidos viscerais drenados pela veia porta, como rúmen e intestinos, são ávidos por energia, especialmente glicose (Huntington, 1997; Reynolds, 2002). O fluxo líquido de glicose na veia porta de bovinos em terminação é normalmente zero ou negativo, devido ao uso intenso deste nutriente pelos tecidos do trato gastrointestinal. Isto levantou a discussão quanto à necessidade de uma quantidade mínima de glicose absorvida pelo intestino delgado. Dados mais recentes têm mostrado que a glicose usada por esses tecidos é proveniente do sangue arterial que irriga o sistema, gerada pela gluconeogênese hepática e não da glicose absorvida pelo intestino delgado (Reynolds, 2002), descartando a hipótese de que a falta de glicose no intestino delgado limitaria o desempenho animal. 
Apesar de não ter sido feita comparação estatística entre o tratamento M e P75, uma vez que este contraste não seria ortogonal (ver item 3.2.5), os valores numéricos para GPD não diferiram entre os tratamentos, apesar da redução na IMS. Com base nestes dados, pode-se novamente inferir que em rações com 70\% de concentrado, quando a proporção PC:MM é 75:25, o valor energético da PC é também subestimado pelo NRC (1996) e NRC (2001).

A eficiência alimentar foi maior $(P<0,10)$ no tratamento $P 50$ em comparação com o tratamento $\mathrm{M}$. A combinação de MM e PC em partes iguais melhorou a eficiência alimentar devido ao aumento no GPD. Teores crescentes de PC na ração (tratamentos P75 e P100) não afetaram ( $P>0,05)$ a eficiência alimentar em comparação com a ração P50. Apesar da redução na IMS e GPD na ração exclusiva de PC (P100) em comparação com as rações contendo combinações de MM e PC (P50 e P75) a eficiência alimentar não foi diferente entre as rações. Numericamente, a eficiência da ração P100 foi pouco melhor que da ração $M$.

Henrique et al. (2004) trabalharam com garrotes Santa Gertrudes e forneceram teores crescentes de PC nas rações (0, 25, 40 e 55\% da MS) em substituição ao milho moído, não observando diferença na eficiência alimentar dos animais. Estes dados reafirmam o que já foi proposto anteriormente, que o NRC (1996) e o NRC (2001) subestimam o valor energético da PC. Outro ponto a ser destacado é que açúcares, pectina e fibra de alta digestibilidade, quando combinados em um alimento como a PC, substituíram o amido de milho sem prejudicar a eficiência alimentar de bovinos em terminação.

\subsubsection{Espessura de gordura e rendimento de carcaça}

A alimentação exerce influência no acabamento do animal e pode levar a alterações na porcentagem de gordura e músculo na carcaça (Luchiari Filho, 1986). O ultra-som em tempo real tem sido aplicado como técnica confiável e de baixo custo para avaliar a qualidade e predizer o abate de bovinos (Silveira, 2004). 
Uma quantidade mínima de gordura subcutânea na carcaça é necessária para garantir a qualidade da carne, pois atua como isolante térmico, protegendo a carcaça do processo de encurtamento das fibras da carne pelas baixas temperaturas empregadas nas camâras frias dos frigoríficos. A espessura de gordura está diretamente relacionada ao total de gordura na carcaça e indiretamente relacionada à quantidade de músculo, portanto quanto maior o acúmulo de gordura, menor a proporção de músculos ou cortes magros da carcaça (Forrest et al.,1975). Segundo Dransfield (1994), quando a carcaça está revestida com uma camada de gordura mínima, a temperatura da carne não declina muito durante seu resfriamento inicial na câmara fria do frigorífico, proporcionando uma rápida queda do $\mathrm{pH}$ e conservando-a adequadamente. Este porcesso ainda facilita a ação das calpaínas que promovem a proteólise das fibras musculares, promovendo maior maciez.

A Figura 3 apresenta o comportamento da deposição de gordura dos tourinhos Canchim do presente experimento. Não houve efeito dos tratamentos na espessura de gordura subcutânea na pesagem final do experimento (Tabela 6). Pode-se observar que os animais começaram a acumular gordura de forma significativa a partir do último período o que explica a queda no GPD nesta fase. Os animais atingiram 3,0 mm de gordura subcutânea no músculo Longissimus dorsi com aproximadamente $490 \mathrm{~kg}$ de peso vivo neste experimento.

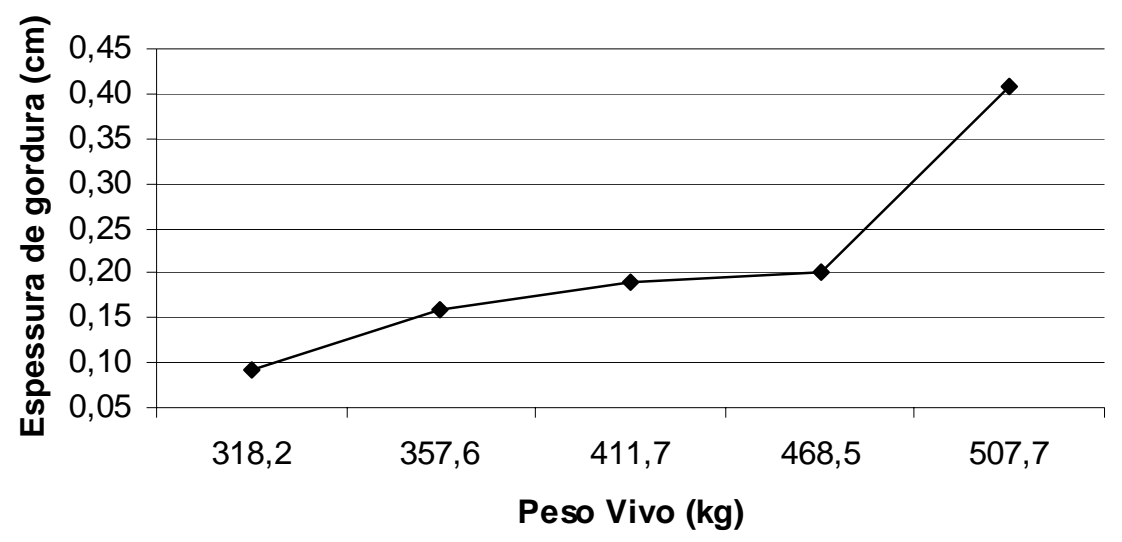

Figura 3 - Deposição de gordura em tourinhos da raça Canchim 
Também foi realizada a avaliação do rendimento de carcaça quente, que é a estimativa da rentabilidade da porção comestível. Este parâmetro é importante para realização da análise econômica dos resultados de desempenho demonstrados e principalmente porque o sistema de engorda em confinamento propicia um melhor rendimento de carcaça que a terminação em pastagem. Os rendimentos de carcaça apresentaram valores homogêneos, sem diferença entre os tratamentos.

No trabalho de Prado et al. (2000), a substituição do milho (40\%, 60\%, $80 \%$ e $100 \%$ ) pela PC em rações com 50\% de silagem de milho e $50 \%$ de concentrado para bovinos mestiços (Nelore x Angus), terminados com 20 meses de idade, não afetou a espessura de gordura e nem o rendimento de carcaça (57\%).

Henrique et al. (1998), trabalharam com tourinhos da raça Santa Gertrudes com o objetivo de avaliar a substituição do milho moído pela PC em rações com $20 \%$ de silagem de milho, e não observaram diferenças no rendimento de carcaça e na espessura de gordura entre as fontes testadas.

Estes dados de espessura de gordura estão em desacordo ao encontrado em tourinhos da raça Santa Gertrudes por Henrique et al. (2004), que observaram através da medida da espessura de gordura da $12^{a}$ costela após abate, menor deposição de tecido adiposo com o aumento da inclusão de 0\%, 25\%, 40\% e 55\% de PC na MS das rações substituindo o milho moído (7,0; 6,0; 5,3 e 4,7 mm de gordura subcutânea, respectivamente). Porém, os autores consideraram que em todos os tratamentos as espessuras de gordura foram suficientes para uma boa proteção de carcaça. O rendimento de carcaça, não foi afetado pelo tipo de fonte energética nesse estudo.

Os valores obtidos entre 3,89 a 4,16 $\mathrm{mm}$ de gordura, para machos Canchim, não castrados, com peso vivo médio de $508 \mathrm{~kg}$ é superior ao mínimo exigido pelos frigoríficos nacionais e próximos a $4 \mathrm{~mm}$ que foi citado por Silveira (2004) como ideal. O valor médio de 57\% de rendimento da carcaça quente pode ser considerado um bom resultado. 


\subsubsection{Cálculos de energia das rações e da polpa cítrica}

Com base nos valores de energia líquida observada (Tabela 7), calculada através das fórmulas apresentadas no item 3.2.6, a combinação de MM e PC em partes iguais (tratamento P50) aumentou $(P<0,10)$ a concentração de energia líquida de manutenção da ração em 5,78\% e a de ganho em 8,11\% comparadas com a ração com MM exclusivo (tratamento $\mathrm{M}$ ). Esta diferença entre os tratamentos M e P50 sugere que o valor energético da PC foi subestimado pelo NRC (1996) e NRC (2001) em comparação ao milho moído fino. Entretanto, pode se observar na Tabela 7, que os valores observados de energia líquida para o MM foram bem abaixo do esperado. No caso da PC os valores observados foram mais próximos do esperado.

Tabela 7. Valor de energia líqüida das rações

\begin{tabular}{|c|c|c|c|c|c|}
\hline \multirow[b]{2}{*}{ Item } & \multicolumn{4}{|c|}{ Tratamentos } & \multirow{2}{*}{ EPM } \\
\hline & $\mathbf{M}$ & P50 & P75 & P100 & \\
\hline \multicolumn{6}{|c|}{ EL observada da ração, Mcal/kg } \\
\hline Manutenção b & 1,73 & 1,83 & 1,76 & 1,78 & 0,040 \\
\hline Ganho $^{\text {b }}$ & 1,11 & 1,20 & 1,13 & 1,15 & 0,036 \\
\hline \multicolumn{6}{|c|}{ EL da ração, observado/esperado } \\
\hline Manutenção ${ }^{a}$ & 0,81 & 0,90 & 0,90 & 0,93 & 0,029 \\
\hline Ganho $^{a}$ & 0,88 & 1,00 & 1,00 & 1,05 & 0,044 \\
\hline
\end{tabular}

${ }^{\mathrm{a}} \mathrm{M}$ vs $\mathrm{P} 50, \mathrm{P}<0,05$

${ }^{\mathrm{b}} \mathrm{M}$ vs $\mathrm{P} 50, \mathrm{P}<0,10$

Nota-se, através da análise dos dados (Tabela 7) que de modo geral, os valores de energia líquida de manutenção observados para as rações, foram inferiores aos valores esperados.

Uma hipótese para explicar os valores observados de EL de manutenção e ganho inferiores ao esperado pode estar em um valor energético da silagem de cana-de-açúcar inferior aos $61 \%$ de NDT estimados pela 
metodologia do NRC (2001) no presente estudo. Este valor é superior a 55-58\% relatados por Pedroso et al. (2004), que estimou esses valores através dos resultados do presente estudo e de mais dois experimentos. Se utilizarmos o valor sugerido por estes autores de 58\% de NDT para a silagem de cana-deaçúcar na simulação de energia esperada no NRC (1996), a relação entre observado:esperado fica mais próxima a 1 . Em sua revisão, Pedroso et al. (2004) encontraram 44\% de NDT para a silagem de cana-de-açúcar do tratamento $\mathrm{M}$ do presente estudo e atribuíram este baixo NDT ao alto valor energético do milho presente nesta ração. Isto explicaria a relação mais próxima a 1 da energia observada:esperada nos tratamentos com PC e a diferença encontrada entres os tratamentos M e P50 $(P<0,05)$. Nos tratamentos com $\mathrm{PC}, \mathrm{o}$ pH ruminal pode ter sido menos crítico para a digestão ruminal da silagem de cana que no tratamento com MM.

Através do método de substituição apresentado por Zinn et al. (2002) foi calculada a energia metabolizável (EM) da PC. As limitações deste método, são que os valores estimados, dependem da acurácia dos valores de EM dos demais alimentos da ração e interações associativas dos ingredientes podem influenciar os resultados encontrados. Porém, é um método que apenas pode ser utilizado quando a única alteração de fonte de energia dentro de experimento é o ingrediente testado, o que lhe atribui maior acurácia que os levantamentos de subtração tabular (Zinn et al., 2002).

Segundo o NRC (1996), a PC possui o NDT 8,9\% menor do que o MM (82 vs 88\% de NDT). Porém, através dos cálculos de EM obtidos neste estudo, pelo método da substituição (Zinn et al., 2002), o valor da PC chegou a ser $6,25 \%$ maior que do MM.

Tomando como base o valor estimado de EM do MM como 3,19 $\mathrm{Mcal} / \mathrm{kg}$ de MS calculado segundo as fórmulas do NRC (1996) com base no NDT estimado pelo NRC (2001), os valores de EM observados para a PC seriam de 3,39 Mcal/kg de MS na ração $\mathrm{P} 50$, de 3,25 Mcal/kg de MS na ração $\mathrm{P} 75$ e 3,26 Mcal/kg de MS na ração P100. Com base nos valores de EM acima obtidos, o NDT da PC no presente experimento teria variado de $90 \%$ a $93,7 \%$ 
da MS, bem superior ao valor de $82 \%$ da tabela do NRC (1996). Vale frisar novamente, que este valor energético elevado estimado para a PC, pode ser conseqüência direta de um provável efeito benéfico deste alimento no ambiente ruminal, que favoreceu a fermentação da porção fibrosa da silagem de cana-deaçúcar em comparação ao tratamento $\mathrm{M}$, rico em amido de milho. Este aspecto pode explicar o maior GPD e a melhor eficiência alimentar do tratamento P50 comparado ao tratamento $\mathrm{M}$.

Como o valor de EM da PC obtido no tratamento P50 (3,39 Mcal/kg de MS), foi muito acima do encontrado nos outros dois tratamentos (P75 e P100), suspeita-se que esta porcentagem de substituição seja um ponto de otimização biológica devido à interações associativas entre as diferentes fontes de carboidratos.

\subsection{Conclusões}

Para bovinos em terminação, alimentados com rações que possuam $70 \%$ de concentrado e 30\% de silagem de cana-de-açúcar, a PC tem valor energético superior ao MM quando substitui 50\% deste cereal e valor energético similar quando substitui 75 ou 100\% do MM.

Em rações para bovinos em terminação, com $70 \%$ de concentrado, os valores de energia da PC, estimados pelo NRC (1996) e NRC (2001), são subestimados em comparação ao MM.

Bovinos de corte em terminação, apresentam desempenho satisfatório quando alimentados com rações com teores mínimos ou quase nulos de amido, quando outros carboidratos de alta degradabilidade ruminal são fornecidos como no caso de rações com PC. 


\section{SUBSTITUIÇÃO DO MILHO POR FARELO DE TRIGO OU FARELO DE GLÚTEN DE MILHO-21 NA RAÇÃO DE BOVINOS EM TERMINAÇÃO}

\section{Resumo}

O experimento foi conduzido no Departamento de Zootecnia da USPESALQ. O objetivo do trabalho foi avaliar a substituição do milho moído fino por farelo de trigo ou farelo de glúten de milho 21 (Refinazil ${ }^{\circledR}$ ou Promill ${ }^{\circledR}$ ) na ração de bovinos em terminação. Foram utilizados trinta e seis machos não castrados (18 Nelore e 18 Canchim), com peso médio inicial de $382 \mathrm{~kg}$ e 14 meses de idade. O delineamento experimental utilizado foi o de blocos ao acaso, com os animais agrupados por raça e peso inicial. O período experimental foi de 87 dias divididos em 3 sub-períodos. As rações continham $76 \%$ de concentrado e 24\% de silagem de capim Tanzânia, formuladas de acordo com o NRC (1996) para serem isoprotéicas e com balanço positivo de proteína degradável no rúmen e proteína metabolizável. As rações foram compostas de silagem de capim, polpa cítrica, farelo de soja, uréia, núcleo mineral e vitamínico, bicarbonato de sódio e monensina sódica, além de uma das fontes energéticas testadas: milho moído fino (MP), farelo de trigo (FTP) e farelo de glúten de milho-21 (FGP). Em todas as rações foi mantida a proporção polpa cítrica: fonte testada de 50\%:50\%. Foram avaliados o ganho de peso diário (kg/dia de PV), a ingestão de matéria seca (kg/dia de MS), a eficiência alimentar (ganho de peso diário/ingestão de matéria seca), a energia líquida para manutenção e ganho das rações (Mcal/kg de MS) e a relação entre a energia líquida calculada com 
os dados do experimento e a predita pelo NRC (1996) nível 1 (observado/esperado). A substituição de milho moído fino por farelo de trigo aumentou a ingestão de fibra em detergente neutro $(P<0,05)$ e não afetou a ingestão de matéria seca $(9,69 \times 9,82 \mathrm{~kg} / \mathrm{dia})$, o ganho de peso diário $(1,42 \times$ $1,38 \mathrm{~kg} / \mathrm{dia})$ nem a eficiência alimentar $(0,147 \times 0,142)$. A substituição de milho moído fino por farelo de glúten de milho 21 reduziu a ingestão de matéria seca $(9,69 \times 9,31 \mathrm{~kg} / \mathrm{dia}, \mathrm{P}<0,05)$ e o ganho de peso diário $(1,42 \times 1,30 \mathrm{~kg} / \mathrm{dia}, \mathrm{P}<$ $0,10)$, não afetou a eficiência alimentar $(0,147 \times 0,142)$ e aumentou a ingestão de fibra em detergente neutro $(P<0,05)$. Os valores observados de energia líquida de manutenção e de ganho das rações, não diferiram entre os tratamentos. A relação energia líquida observado/esperado do tratamento com milho moído fino foi menor que da ração com farelo de trigo e da com farelo de glúten de milho $21(P<0,10)$.

\section{SUBSTITUOTION OF WHEAT MIDDLING OR CORN GLUTEN FEED FOR CORN IN FEEDLOT FINISHING DIETS}

\section{Summary}

The trial was conducted at the Animal Sciences Department, USPESALQ. Thirty six yearling bulls (18 Nelore and 18 Canchim), averaging $382 \mathrm{~kg}$ initial live weight, and 14 months old were used to evaluate the substitution of wheat middling or corn gluten feed for corn grain in feedlot finishing diets. The animals were assigned in a randomized complete block design, and grouped by breed and live weight. Experimental period lasted 87 days, with 3 sub-periods. Diets contained grass silage, dried citrus pulp, soybean meal, urea, mineralvitamin mix, sodium bicarbonate, sodium monensin, and one of the energy sources tested, balanced according to NRC (1996) to be isonitrogenous with 
positive rumen degradable protein and metabolizable protein balances. Treatments were fine ground corn (MP), wheat middling (FTP) and dried corn gluten feed (FGP). All diets contained a 50:50\% ratio between dried citrus pulp and the tested energy source. Variables evaluated were daily weight gain (GPD, kg/day), dry matter intake (IMS, kg MS/day), feed efficiency (EA, kg GPD/kg IMS), diets net energy for maintenance and gain values, and the ratio between calculated net energy, using experimental data, and net energy predicted by NRC (1996), level 1 (observed/predicted). The substitution of wheat middling for corn elevated NDF intake $(P<0,05)$, and did not affect $(P>0,05)$ IMS $(9,69 x$ $9,82)$, GPD $(1,42 \times 1,38)$ neither EA $(0,147 \times 0,142)$. Substitution of corn gluten feed for corn reduced IMS $(9,69 \times 9,31, P<0,05)$ and GPD $(1,42 \times 1,30, P<0,10)$, did not affect EA $(0,147 \times 0,142)$, and elevated NDF intake $(P<0,05)$. Observed values for diets net energies of maintenance and gain did not differ among treatments $(P>0,05)$. According to experimental data, NRC (1996) underestimated the FTP and FGP treatments observed/expected net energy ratios, compared to MP treatment.

\subsection{Introdução}

No Brasil o aumento no custo de produção de volumosos, a melhoria da qualidade dos animais, a disponibilidade crescente de subprodutos e grãos e o surgimento de grandes confinamentos, tem estimulado a adoção de rações com alto teor de concentrado. De maneira geral, grãos de cereais em especial o milho, representam a principal fonte de energia das rações. Entretanto, a disponibilidade crescente de diversos subprodutos, tem aumentado o interesse por estas fontes alternativas com o objetivo de baixar o custo da arroba produzida (Santos et al., 2004).

Além da diminuição no custo da ração, a inclusão de determinados subprodutos em rações ricas em concentrado, pode ter efeito benéfico no ambiente ruminal devido à redução no teor de amido. A substituição parcial ou total da fonte de amido por subprodutos ricos em pectina e fibra de alta 
digestibilidade tem resultado em desempenho superior de bovinos em terminação, em diversos trabalhos compilados por Blasi et al. (2001) e Santos et al. (2004).

Para bovinos em confinamento, a polpa cítrica (PC), casca de soja, caroço de algodão, farelo de trigo (FT) e farelo de glúten de milho 21 (FGM-21) são alguns dos subprodutos de âmbito regional, que podem se constituir em alternativas ao milho, em função dos preços praticados.

A PC não contém amido, porém é rica em açúcares, pectina e fibra de alta digestibilidade, capaz de suprir alta quantidade de energia para os microrganismos ruminais (Carvalho, 1995).

Segundo o NRC (1996) e Fox et al. (1992), o FT contém normalmente 17 a 18\% de proteína bruta (PB), 35 a 43\% de fibra em detergente neutro (FDN) e 70 a $80 \%$ de nutrientes digestíveis totais (NDT). Sua proteína apresenta alta degradabilidade, e o alimento como um todo exprime alta degradabilidade inicial quando comparado com outros subprodutos (Machado, 2001). Sua fibra apresenta pequeno efeito estimulante de ruminação quando comparado com as forragens, devido ao reduzido tamanho de partículas (Dhuyvetter et al., 1999). Seu teor de amido é baixo, ao redor de 31,3\% (Hinders, 2000) quando comparado aos grãos de cereais.

O FGM-21 apresenta características interessantes, como baixo teor de gordura e amido, sendo rico em fibra altamente digestível. Estas características o tornam uma ótima alternativa para inclusão em rações com alta porcentagem de grãos. Por apresentar concentrações mais elevadas de fibra em detergente ácido (FDA) e FDN do que grãos de cereais, sua utilização pode levantar questões sobre a concentração energética e limitação ao consumo das rações. Mas, possíveis efeitos benéficos no ambiente ruminal de bovinos alimentados com rações de alto teor de concentrado, podem compensar seu menor teor em carboidratos não fibrosos que grãos de cereais (Fellner e Belyea, 1991). 
Dados experimentais de substituição do milho moído fino (MM) por FT ou FGM-21 para bovinos em terminação são escassos em nossas condições, especialmente em rações com PC.

A finalidade deste projeto foi avaliar o efeito da utilização de ingredientes alternativos, o FT ou o FGM-21, em substituição total ao MM em rações com PC para bovinos em terminação e estimar a energia líquida de manutenção e de ganho das rações com os subprodutos avaliados, através do desempenho animal observado.

\subsection{Material e Métodos}

\subsubsection{Animais e instalações experimentais}

O experimento foi conduzido por 87 dias, com início em 29/12/2003, nas instalações de confinamento do Departamento de Zootecnia da USPESALQ. Não foi realizada adaptação para o início do experimento uma vez que os animais já estavam confinados e consumiam ração com elevada porcentagem de concentrado. Foram utilizados 36 machos não castrados das raças Canchim e Nelore, com média de 14 meses de idade e $382 \mathrm{~kg}$ de peso vivo inicial, alojados em 12 baias $(3 \times 11 \mathrm{~m})$ cobertas e com piso de concreto. Os animais foram everminados com produto com princípio ativo Abamectina e receberam doses injetáveis de complexo vitamínico $A D E$, ambos nos dias 0 e 58 do período experimental. O período experimental foi dividido em 3 subperíodos.

\subsubsection{Tratamentos}

As rações continham $24 \%$ de silagem de capim Tanzânia e $76 \%$ de concentrado na matéria seca (Tabela 8). A diferença entre os tratamentos experimentais foi a utilização do FT ou do FGM-21 em substituição ao MM. 
Tabela 8. Composição das rações experimentais

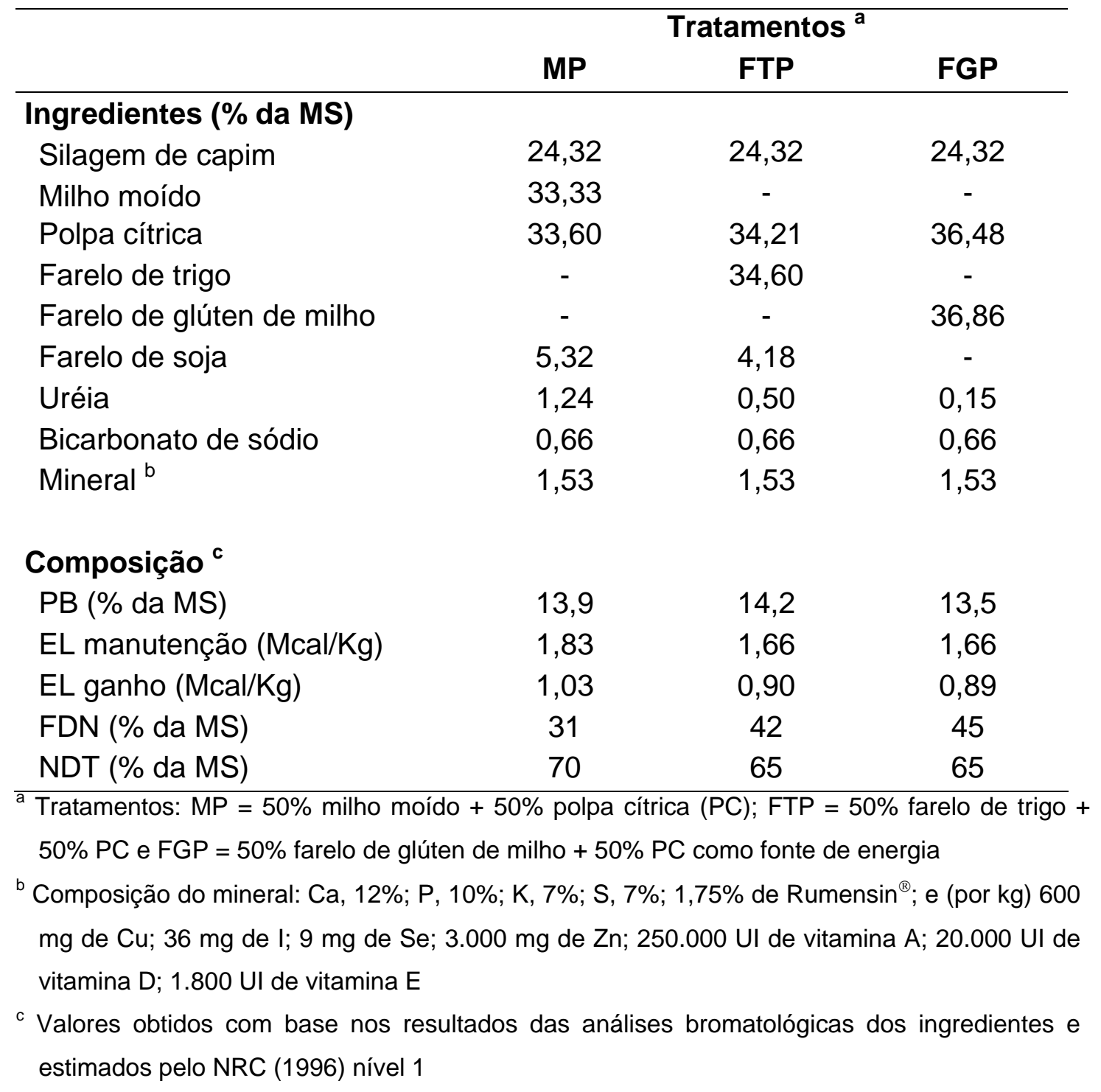

As rações foram formuladas para serem isoprotéicas e atenderem as exigências de proteína degradável no rúmen e proteína metabolizável dos animais, de acordo com o NRC (1996) nível 1. Porém, foram utilizadas partidas diferentes de alguns ingredientes durante o período experimental devido a compra parcelada. A variação nos teores de proteína bruta (PB) entre as partidas durante o período experimental, provocou uma diferença nos teores de PB das rações (Tabela 8), que foram formuladas com base na partida inicial. 
Mas estas mudanças não comprometeram o desempenho dos animais pois, em todos os tratamentos, a proteína degradável e metabolizável atendia as exigências dos animais.

O tratamento controle (MP), continha 50\% de MM e 50\% de PC como fontes energéticas. Este teor de inclusão de PC foi o que apresentou melhor desempenho animal no experimento 1 (capítulo 3). O tratamento FTP continha FT e PC na proporção 50:50 e o tratamento FGP continha FGM-21 e PC na proporção 50:50\%. Foi utilizado o mesmo núcleo mineral para todos tratamentos, que supriu as exigências minerais dos animais (NRC, 1996).

Os concentrados eram misturados previamente em misturador horizontal (marca Lucato, capacidade de $250 \mathrm{Kg}$ ). O fornecimento da ração foi feito diariamente às 9:00 horas, com vagão para ração completa (marca Siltomac, com capacidade de $2.000 \mathrm{Kg}$ ).

\subsubsection{Coleta de dados e análises bromatológicas}

Sub-amostras dos ingredientes utilizados nas rações foram coletadas semanalmente e conservadas congeladas $\mathrm{a}-10^{\circ} \mathrm{C}$. Amostras da silagem foram secas a $55{ }^{\circ} \mathrm{C}$ para determinação de matéria seca (MS) a fim de se proceder o ajuste semanal da formulação das rações.

No preparo para análise laboratorial, as sub-amostras foram descongeladas, compostas por ingrediente e secas em estufas com ventilação forçada $\left(55^{\circ} \mathrm{C}\right.$ ) por 72 horas (Silva, 1990). Posteriormente, as sub-amostras de cada ingrediente foram moídas em moinhos tipo Wiley, providos de peneiras com malha de 1 e $2 \mathrm{~mm}$, compostas em uma única amostra e analisadas para MS segundo Silva (1990); matéria mineral, extrato etéreo e PB de acordo com AOAC (1990); FDN e FDA de acordo com o método de Van Soest et al. (1991) e o NDT foi estimado pela metodologia do NRC (2001).

Foi realizado antes do início do experimento uma avaliação da granulometria do MM través da metodologia de Yu et al. (1998), para verificar 
se o tamanho médio de partícula do milho estava dentro do padrão definido como fino $(1,2 \mathrm{~mm})$.

Os animais foram pesados após jejum alimentar de 12 horas no início e no final de cada sub-período experimental. Através dos dados de ganho de peso vivo diário (GPD) e da IMS, foram calculadas a eficiência alimentar dos tratamentos, que é a relação entre o GPD/IMS.

\subsubsection{Delineamento experimental e análise estatística}

O delineamento experimental utilizado foi o de blocos casualizados. Os animais foram agrupados em blocos de acordo com a raça e o peso vivo (PV) inicial. Foram alocados três animais por baia (unidade experimental) e quatro baias por tratamento. Os dados foram analisados pelo procedimento MIXED do programa estatístico SAS (1999), versão 8 para Windows.

Para verificar os efeitos sobre as variáveis estudadas, foi realizada a comparação entre médias, utilizando-se do teste de Dunnett para fins de comparação entre os tratamentos MP x FTP e MP x FGP e foram consideradas significativas diferenças com até $10 \%$ de probabilidade $(P<0,10)$. As médias foram obtidas pelo método dos quadrados mínimos (LSMEANS). Na Tabela 9 é apresentado o quadro de análise de variância proposto.

Tabela 9. Resumo esquemático da análise de variância

\begin{tabular}{cc}
\hline Causas de Variação & Graus de Liberdade \\
\hline Bloco & 3 \\
Tratamento & 2 \\
Resíduo A & 6 \\
Sub total & 11 \\
Período & 2 \\
Período x Tratamento & 4 \\
Resíduo B & 18 \\
Total & 35 \\
\hline
\end{tabular}


Todos os dados foram testados para se verificar a distribuição normal dos erros, utilizando-se o procedimento UNIVARIATE (SAS, 1999). Os dados que apresentaram erros fora do intervalo entre \pm 3 desvios foram arbitrariamente descartados da análise estatística (Imaizumi, 2005).

\subsubsection{Cálculo de energia líqüida das rações}

Os valores de energia líquida observada das rações foram calculados com base nos dados de IMS e GPD observados neste experimento. Para tal, foram utilizadas as fórmulas a seguir, segundo a metodologia proposta por Zinn \& Shen (1998). Primeiro, foram calculadas as exigências de ganho e de manutenção dos animais através das fórmulas 7 e 8 , respectivamente. Calculadas as exigências energéticas relacionadas aos GPD (kg/dia) e aos pesos metabólicos $(\mathrm{kg})$ dos animais durante os três períodos experimentais, calculou-se então energia líquida das rações (Mcal/kg de MS) para manutenção e ganho através das fórmulas 9 e 10.

$$
\begin{gathered}
E_{g}=\left[0,0493 P^{0,75}\right] G P D^{1,097} ;(N R C, 1984) \\
E_{m}=0,077 P^{0,75} ;(\text { Lofgreen \& Garrett, 1968; citados por Zinn \& Shen, 1998) } \\
\left.E L_{m}=\left(-b-\left(\left(b^{2}\right)-(4 a c)\right)^{0,5}\right)\right) /(2 a) ;(\text { Zinn \& Shen, 1998) } \\
a=-0,877 \text { IMS } \\
b=0,877 E_{m}+0,41 \text { IMS }+E_{g} \\
c=-0,41 E_{m}
\end{gathered}
$$

$$
E L_{g}=0,877 E L_{m}-0,41 ;(\text { Zinn \& Shen, 1998) }
$$


Onde, $E_{g}=$ exigência em energia para ganho (Mcal/dia)

$$
\begin{aligned}
& \mathrm{E}_{\mathrm{m}}=\text { exigência em energia para manutenção (Mcal/dia) } \\
& \mathrm{EL}_{\mathrm{m}}=\text { energia líqüida de manutenção (Mcal/kg de MS) } \\
& \mathrm{EL}_{\mathrm{g}}=\text { energia líqüida de ganho (Mcal/kg de MS) }
\end{aligned}
$$

Os dados médios de cada baia (unidade experimental) de IMS, GPD, peso vivo e idade foram utilizados para avaliar como o modelo do NRC (1996) nível 1 foi capaz de predizer a energia líqüida das rações em comparação com os valores calculados através dos resultados obtidos.

Foram então calculadas as relações entre concentração de energia observada:energia esperada. A energia observada foi aquela encontrada através do método acima e a esperada calculada pela metodologia do NRC (1996), que utiliza o NDT da ração para este cálculo.

Para o cálculo do NDT dos ingredientes deste experimento, utilizou-se os valores de análise bromatológica. Esses valores de NDT foram utilizados para o cálculo de energia líquida esperada de manutenção e de ganho das rações (NRC, 1996).

\subsection{Resultados e discussão}

\subsubsection{Composição química dos ingredientes}

Os dados de composição bromatológica dos ingredientes das rações são apresentados na Tabela 10.

Os teores de PB do FT e do FGM-21 encontram-se dentro da faixa relatada na literatura (NRC, 1996; Santos et al., 2004). Os teores de FDN do FT 
e especialmente do FGM-21 encontram-se mais altos que os relatados pelo NRC (1996).

Tabela 10. Composição química, em porcentagem da MS, dos ingredientes

\begin{tabular}{lcccccc}
\hline Item & $\begin{array}{c}\text { Silagem } \\
\text { de } \\
\text { capim }\end{array}$ & $\begin{array}{c}\text { Farelo } \\
\text { de } \\
\text { soja }\end{array}$ & $\begin{array}{c}\text { Polpa } \\
\text { cítrica }\end{array}$ & $\begin{array}{c}\text { Milho } \\
\text { moído } \\
\text { fino }\end{array}$ & $\begin{array}{c}\text { Farelo } \\
\text { de } \\
\text { trigo }\end{array}$ & $\begin{array}{c}\text { Farelo } \\
\text { glúten } \\
\text { milho }\end{array}$ \\
\hline Matéria seca & 27,07 & 94,24 & 93,93 & 92,88 & 93,67 & 93,27 \\
Proteína bruta & 7,56 & 47,62 & 7,63 & 10,19 & 18,03 & 22,80 \\
Extrato etéreo & 1,70 & 2,18 & 2,03 & 6,87 & 5,60 & 3,25 \\
Matéria mineral & 11,24 & 7,45 & 8,53 & 1,80 & 4,72 & 5,14 \\
FDN & 74,39 & 18,92 & 25,24 & 10,18 & 41,60 & 48,63 \\
FDA & 48,62 & 10,67 & 24,37 & 2,79 & 12,05 & 12,17 \\
NDT ${ }^{1}$ & 46,41 & 79,15 & 74,65 & 88,26 & 71,99 & 71,84 \\
\hline${ }^{1}$ calculado de acordo com metodologia proposta pelo NRC $(2001)$ & &
\end{tabular}

O valor estimado de NDT (NRC, 2001) para o MM foi de 88,26\%. O NRC (2001) apresenta em sua biblioteca valores de NDT de $85 \%$ para milho quebrado, 88,7\% para milho moído e 91,7 para milho floculado. Porém, o valor do extrato etéreo obtido de 6,87 , foi muito acima dos valores padrões de $4,2 \%$ (NRC, 2001) e 4,3\% (NRC, 1996).

O teor de NDT estimado para a PC foi de $74,65 \%$, contra $82 \%$ proposto pelo NRC (1996) e 78,9\% proposto pelo NRC (2001) como ocorrido no experimento 1 (capítulo 3). Os teores estimados para o FT e FGM-21 também ficaram abaixo do sugerido na literatura (71,99\% e 71,84\%, respectivamente). Hinders (2000), obteve valor de NDT de 73\% para o FT e Hopkins (2002) 78\% para o FGM-21, enquanto o NRC (1996) apresenta valores de 83\% e 80\%, respectivamente. Estes valores sugerem que a substituição de milho pelos ingredientes testados neste experimento, deveria prejudicar o desempenho animal. 


\subsubsection{Desempenho animal}

Os dados de IMS e desempenho animal são apresentados na Tabela 11.

Tabela 11. Efeito dos tratamentos no desempenho animal

\begin{tabular}{lcccc}
\hline & \multicolumn{3}{c}{ Tratamentos } & \multirow{2}{*}{ EPM } \\
Item & MP & FTP & FGP & \\
\hline Baias por tratamento & 4 & 4 & 4 & \\
Peso vivo inicial, kg & 379,1 & 386,4 & 381,1 & \\
Peso vivo final, kg & 503,7 & 498,3 & 496,3 & \\
GPD, kg/dia ${ }^{b}$ & 1,42 & 1,38 & 1,30 & 0,058 \\
IMS, kg/dia ${ }^{\text {a }}$ & 9,69 & 9,82 & 9,31 & 0,151 \\
Ingestão de FDN, kg de MS/dia ac & 2,96 & 3,99 & 4,06 & 0,113 \\
Eficiência alimentar & 0,147 & 0,142 & 0,142 & 0,006 \\
${ }^{a}$ MP vs FGP, P $<0,05$ & & & & \\
${ }^{\mathrm{b}}$ MP vs FGP, P $<0,10$ & & & & \\
${ }^{\mathrm{c}}$ MP vs FTP, $P<0,05$ & & & &
\end{tabular}

Encontram-se casos de queda da IMS apenas quando o farelo de glúten de milho na forma úmida participou em mais de $50 \%$ da MS da ração de vacas leiteiras (Fellner et al., 1988 e Staples et al., 1984), portanto de difícil comparação com o presente experimento. A substituição do MM por FT (MP X FTP) também ocasionou um aumento de FDN na ração porém, não causou redução na IMS $(9,69 \times 9,82 \mathrm{~kg} / \mathrm{dia}$, respectivamente). Entretanto, não houve diferença na ingestão de FDN (kg de MS/dia) entre os tratamentos FTP e FGP (Tabela 11 e Figura 4). 
Sub-períodos

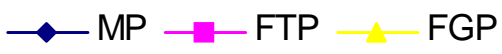

Figura 4 - Ingestão de fibra em detergente neutro durante o experimento

Uma segunda hipótese que poderia ser levantada para explicar essa diferença de comportamento na IMS, seria a ausência de farelo de soja no tratamento FGT. Isto poderia ter limitado a disponibilidade de proteína metabolizável no intestino delgado. Tem sido sugerido que o aporte de proteína para o intestino delgado possa interferir com a IMS (NRC, 1996). Santos et al. (1998) relataram que a qualidade da proteína de subprodutos do milho é inferior ao da proteína do farelo de soja. A proteína do milho e seus subprodutos é rica em metionina, porém pobre em lisina. Limitação de lisina, especialmente em presença de doses altas de metionina, pode afetar a IMS e o desempenho animal. Entretanto, na grande maioria dos trabalhos revisados por Santos et al. (2004), quando o FGM-21 substituiu o milho, essas rações, assim como no presente estudo, também não continham farelo de soja. Portanto, não se pode descartar ainda uma terceira hipótese para explicar esses efeitos na IMS: o efeito de aceitabilidade deste subproduto, na redução da IMS neste estudo.

O GPD observado foi de 1,42, 1,38 e 1,30 kg/dia para os tratamentos MP, FTP e FGP respectivamente. Esses dados mostram que é possível se obter ganhos de peso satisfatórios com bovinos em terminação alimentados com rações ricas em subprodutos como PC, FT e FGM-21. Entretanto, a 
substituição do MM por FGM-21 (1,42 x 1,30 kg/dia) reduziu o GPD dos animais $(P<0,10)$. Na revisão de Santos et al. (2004) e de Blasi et al. (2001) o GPD foi maior com o FGM-21. Isto foi atribuído a uma possível melhora no ambiente ruminal, que possibilitou uma IMS maior. Como neste estudo a IMS foi reduzida pelo FGM-21, é natural que tenha ocorrido uma redução no GPD dos animais.

Numericamente, a substituição do MM por FT reduziu o GPD. A revisão de literatura mostrou que nos poucos trabalhos onde o milho foi substituído por FT, o GPD de bovinos em terminação foi levemente reduzido. Em nenhum estudo revisado, o FT foi capaz de mostrar o efeito positivo observado com o FGM-21 relatados por Blasi et al. (2001) e por Santos et al. (2004).

A eficiência alimentar (GPD/IMS) não foi diferente $(P>0,05)$ entre os tratamentos. Os valores observados foram 0,147, 0,142, 0,142 (kg de GPD/kg de MS ingerida), respectivamente para os tratamentos MP, FTP e FGP. Apesar da redução na IMS e no GPD na ração com FGM-21 em comparação com o tratamento MP a eficiência alimentar não foi diferente entre as rações. Santos et al. (2004) na compilação de 17 dados de avaliação do FGM-21 substituindo MM ou milho laminado, encontrou redução na eficiência alimentar de oito dados, aumento em oito e igualdade em um dos resultados.

\subsubsection{Cálculo de energia das rações}

Em acordo com os resultados discutidos no item anterior, os valores observados de energia líquida de manutenção (1,89; 1,88; e 1,89 Mcal/kg de MS) e de ganho $(1,25 ; 1,14 ; 1,25 \mathrm{Mcal} / \mathrm{kg}$ de MS) das rações MP, FTP e FGP, respectivamente, não foram diferentes ( $P>0,05$; Tabela 12).

Esta indiferença de energia líquida das rações, lança a hipótese de que a energia metabolizável dos subprodutos utilizados neste experimento é subestimada pelo NRC (1996) e NRC (2001). 
Tabela 12. Valor de energia líquida das rações

\begin{tabular}{|c|c|c|c|c|}
\hline \multirow[b]{2}{*}{ Item } & \multicolumn{3}{|c|}{ Tratamentos } & \multirow{2}{*}{ EPM } \\
\hline & MP & FTP & FGP & \\
\hline \multicolumn{5}{|c|}{ EL da ração, Mcal/kg } \\
\hline Manutenção & 1,89 & 1,88 & 1,89 & 0,061 \\
\hline Ganho & 1,25 & 1,24 & 1,25 & 0,054 \\
\hline \multicolumn{5}{|c|}{ EL da ração, observado/esperado } \\
\hline Manutenção ab & 1,03 & 1,13 & 1,14 & 0,033 \\
\hline Ganho ab & 1,21 & 1,37 & 1,40 & 0,054 \\
\hline
\end{tabular}

A relação entre os valores observados e esperados de energia líquida das rações, diferiu $(P<0,10)$ entre o tratamento MP e os demais tratamentos (FTP e FGP). Os valores observados para o tratamento MP, foram mais próximos dos valores esperados que para os tratamentos FTP e FGP. Essas relações reforçam a idéia de que as estimativas de NDT pela metodologia do NRC (2001), foram razoáveis para a ração com MM, porém subestimaram os valores energéticos do FT e do FGM-21. O mesmo ocorre quando se adotam os valores energéticos sugeridos pelo NRC (1996) para estes dois subprodutos.

\subsection{Conclusões}

Para bovinos em terminação alimentados com rações com $76 \%$ de concentrado, dos quais 33,6\% é representado por PC e 33,3 por MM, este último pode ser substituído na íntegra por FT ou por FGM-21, sem que haja queda na eficiência alimentar ou no teor de energia das rações.

O NDT calculado pela metodologia do NRC (2001) e as estimativas de energia líquida propostas pelo NRC (1996) para o FT e para o FGM-21 foram subestimadas, para bovinos em terminação. 
A redução na IMS com o fornecimento de FGM-21 está em desacordo com a quase totalidade dos dados da literatura e necessita ser melhor estudada. Apesar de apresentar a mesma eficiência alimentar que a ração com MM, o menor GPD na ração com FGM-21 pode ter impacto negativo na lucratividade do confinamento, dependendo dos preços destes ingredientes. 


\section{CONCLUSÕES GERAIS}

Através do estudo supra apresentado, a polpa cítrica, o farelo de trigo e o farelo de glúten de milho 21 quando substituíram o milho moído fino nas variadas proporções, não diminuíram a eficiência alimentar ou o teor de energia de nenhuma das rações, demonstrando serem boas fontes alternativas de energia.

Bovinos de corte em terminação, apresentam desempenho satisfatório quando alimentados com rações que possuem teores mínimos ou quase nulos de amido, quando outros carboidratos de alta degradabilidade ruminal são fornecidos, a exemplo da polpa cítrica, utilizada neste experimento.

É provável que a metodologia do NRC (2001) para estimativa de nutrientes digestíveis totais subestime a energia da polpa cítrica, do farelo de trigo e do farelo de glúten de milho 21 pois, em nenhuma situação neste estudo a substituição do milho moído fino por um destes subprodutos fez com que eficiência alimentar da ração diminuísse, devendo esta hipótese ser melhor estudada. 


\section{REFERÊNCIAS BIBLIOGRÁFICAS}

ASSOCIAÇÃO BRASILEIRA DOS EXPORTADORES DE CITRUS. Produção de laranja - Série histórica. <http://www.abecitrus.com.br>. (30 maio 2004).

ALLEONI, G.F.; LEME, P.R.; BOIN, C. et al. Utilização do refinazil úmido em substituição a um concentrado de milho com farelo de algodão em rações de confinamento. Boletim da Indústria Animal, v. 47, n. 1, p. 67-71, 1990.

ASSIS, A.J.; CAMPOS, J.M.S.; VALADARES FILHO, S.C. et al. Polpa cítrica em dietas de vacas em lactação 3. Consumo e efeito do período de coleta sobre a digestibilidade dos nutrientes. In: REUNIÃO ANUAL DA SOCIEDADE BRASILEIRA DE ZOOTECNIA, 38., Piracicaba, 2001. Anais. Piracicaba: SBZ, 2001. p.1057-1058.

ASSOCIATION OF OFFICIAL ANALYTICAL CHEMISTS. Official Methods of Analysis. 15 ed. Arlington, 1990. v.1, 1117 p.

BEN-GHEDALIA, D.; YOSEF, E.; MIRON, J. et al. The effects of starch and pectin rich diets on quantitative aspects of digestion in sheep. Animal Feed Science Technology, v.24, p. 289-298, 1989.

BERNARD, J.K. Utilization of wet corn gluten feed in a commercial dairy. Tennessee Farmer Home Science, v. 163, p. 10-14, 1992. 
BLASI, D.A.; BROUK, M.J.; DROUILLARD, J.S. et al. Corn gluten feed, composition and feeding value for beef and dairy cattle. Manhattan: Kansas State University, Agricultural Experimental Station and Cooperative Extension Service, 2001. 14p. (MF-2488).

BLASI, D.A.; DROUILLARD, J.S.; KUHL, G.L. et al. Wheat middilings in ruoghage based or limit-fed, high concentrate diets for growing calves. Cattlemen's Day, p. 1-56, 1998a.

BLASI, D.A.; KUHL, G.L.; DROUILLARD, J.S. et al. Wheat middilings composition, feeding value and storage guidelines. Manhattan: Kansas State University, Agricultural Experimental Station and Cooperative Extension Service, 1998b. 21p. (MF-2353).

BOIN, C.; ALEONI, G.F.; BEISMAN, D.A. Fibra úmida de grão de milho na alimentação animal. Comunicações Científicas da Faculdade de Medicina Veterinária e Zootecnia da USP, v. 9, n. 2, p. 187, 1985.

CARVALHO, M.P. Citros. In: SIMPÓSIO SOBRE NUTRIÇÃO ANIMAL, 6., Piracicaba, 1995. Anais. Piracicaba: FEALQ, 1995. p. 153-169.

CARVALHO, M.P. Substituição do milho por subprodutos energéticos em dietas de bovinos à base de bagaço de cana tratado à pressão e vapor: digestibilidade e parâmetros ruminais. Piracicaba, 1998. 101 p. Dissertação (Mestrado) - Escola Superior de Agricultura "Luiz de Queiroz", Universidade de São Paulo. 
CHAMBERLAIN, D.G.; ROBERTSON, S.; CHOUNG, J.J. Sugar versus starch as supplements to grass silage: effects on ruminal fermentation and the supply of microbial protein to the small intestine, estimated from the urinary excretion of purine derivatives, in sheep. Journal of the Science of Food and Agriculture, v.63, p.189-194, 1993.

CHESSON, A .; MONRO, J. Legume pectic substances and their degradation in the ovine rumen. Journal of the Science of Food and Agricuture, v.33, p.852-859, 1982.

COETZER, C.M.; DROUILLARD, J.S.; COETZER, E. et al. Effects of supplementing limit-fed, wheat middling-based diets whit either soybean meal or non-enzymatically browned soybean meal on growing steer performance. Cattlemen's Day, p. 84-86, 1999.

COOPERATIVA NACIONAL DE ABASTECIMENTO - Estimativa da produção de grãos. <http://www.conab.gov.br/safras.asp>. (20 fev. 2004).

DHUYVETTER, J.; HOPPE, K.; ANDERSON, V. Wheat middlings: a useful feed for cattle. Fargo: North Dakota State University, 1999. 11p.

DRANSFIELD, E. Modelling post-mortem tenderisation. V: inactivation of calpains. Meat Science, v.37, p.391, 1994.

DROUILLARD, J.S.; IVES, S.E.; ANDERSON, D.W. et al. Comparative value of dry-rolled corn, distiller's dried grains, and wheat middlings for receiving diets. Cattlemen's Day, p. 81-83, 1999.

EZEQUIEL, J.M.B. Uso da polpa cítrica na alimentação animal. In: SIMPÓSIO GOIANO SOBRE MANEJO E NUTRIÇÃO DE BOVINOS, 3., Goiânia, 2001. Anais. Goiânia: CBNA, 2001. p.329-346. 
FAHEY, G.C.; BERGER, L.L. Carbohydrate nutrition of ruminants. In: $\mathrm{CHURCH}$, D.C. (Ed). The ruminant animal digestive physiology and nutrition. Inglewood Cliffs: Prentice Hall, 1988. p.269-297.

FEGEROS, K.; ZERVAS, G.; STAMOULI, S. et al. Nutritive value of dried citrus pulp and its effect on milk yield and milk composition of lactating ewes. Journal of Dairy Science, v.78, p. 1116-1121, 1995.

FELLNER, V.; BELYEA, L. Maximizing gluten feed in corn silage diets for dairy cows. Journal of Dairy Science, v.74, p. 996-1005, 1991.

FELLNER, V.; BELYEA, R.L.; STEEVENS, B.J. et al. Nutritive value and feeding management of corn gluten feed. Journal of Animal Science, v.71, p.215, 1988.

FIRKINS, J.L. Effects of feeding nonforage fiber sources on site of fiber digestion. Journal of Dairy Science, v.80, p. 1426-1437, 1997.

FIRKINS, J.L.; BERGER, L.L.; FAHEY JUNIOR, G.C. Evaluation of wet and dry distillers grains and wet and dry corn gluten feeds for ruminants. Journal of Animal Science, v.60, p. 847, 1985.

FNP CONSULTORIA \& AGROINFORMATIVOS. Anualpec 2002 : anuário da pecuária brasileira. São Paulo, 2002. 87p.

FORREST, J.C.A.; ABERLE, E.D.A.; HEDRICK, H.B. et al. Principles of meat science. San Francisco: W.H. Freeman, 1975. 417 p.

FOX, D.G.; SNIFFEN, C.J.; O'CONNOR, J.D. et al. A net carbohydrate and protein system for evaluating cattle diets: III. Cattle requirements and diet adequacy. Journal of Animal Science, v.70, p. 3578-3596, 1992. 
FUNDAÇÃO CARGILL. Produtos de milho processados por via úmida para o uso em rações. Campinas, 1980. 20p.

GABARRA, P.R. Digestibilidade de nutrientes e parâmetros ruminais e sangüíneos de novilhos nelore alimentados com fontes protéicas e energéticas com diferentes degradabilidades ruminais. Piracicaba, 2001. 94p. Dissertação (Mestrado) - Escola Superior de Agricultura "Luiz de Queiroz", Universidade de São Paulo.

GRAY, G.M. Starch digestion and absorption in nonruminants. Journal of Nutrition, v.122, p.172, 1992.

HAM, G.A.; STOCK, R.A.; KLOPFENSTEIN, T.J.; HUFFMAN, R.P. Determing the net energy value of wet and dry corn gluten feed in beef growing and finishing diets. Journal of Animal Science, v. 73, p. 353-359, 1995.

HENRIQUE, W.; LEME, P.R.; LANNA, D.P.D. et al. Substituição de amido por pectina em dietas com diferentes níveis de concentrado. 1. Desempenho animal e características de carcaça. Revista Brasileira de Zootecnia, v.27, n.6, p.1206-1211, 1998.

HENRIQUE, W.; SAMPAIO, A.A.M.; LEME, P.R. et al. Desempenho e características da carcaça de tourinhos Santa Gertrudes confinados, recebendo dietas com alto concentrado e níveis crescentes de polpa cítrica peletizada. Revista Brasileira de Zootecnia, v.33, p.463-470, 2004.

HENTGES JUNIOR, J.F.; MORE, J.E.; PALMER, A.Z. et al. Replacement value of dried citrus meal for corn meal in beef cattle diets. Granesville: Florida Agricultural Experimental Station, 1966. 22p. (Bulletin, 708). 
HINDERS, R. Common byproduct feedstuffs nutrient profiles confirmed in California study. Feedstuffs, v.72, n.38, p.10, 2000.

HOPKINS, B.A.; WHITLOW, L.W. Recommendations for feeding selected by-product feeds to dairy cattle. Fargo: North Carolina State University Cooperative Extension Service, 2002. 4p. (ANS 01-205D).

HUNTINGTON, G.B. Starch utilization by ruminants: from basics to the bunk. Journal of Animal Science, v.75, p.852-867, 1997.

HUSSEIN, H.S.; BERGER, L.L. Effects of feed intake and dietary level of wet corn gluten feed on feedlot performance, digestibility of nutrients, and carcass characteristics of growing-finishing beef heifers. Journal of Animal Science, v.73, n.11, p.2905-2912, 1995.

IMAIZUMI, H. Suplementação protéica, uso de subprodutos agroindustriais e processamento de milho em dietas para vacas leiteiras em confinamento. Piracicaba, 2005. 182 p. Tese (Doutorado) - Escola Superior de Agricultura "Luiz de Queiroz", Universidade de São Paulo.

KEITH, S.L.; DONALD, R.G. The use of wheat middlings in Oklahoma cattle feeds. Norman: Oklahoma State University, Division of Agricultural Sciences and Natural Resources, Cooperative Extension Service, 1991. 15p. (Circular E-919).

KREHBIEL, C.R.; STOCK, R.A.; HEROLD, D.W. et al. Feeding wet corn gluten feed to reduce subacute acidosis in cattle. Journal of Animal Science, v.73, n.10, p.2931-2939, 1995. 
LAWRENCE, T.L.J.; FOWLER, V.R. Compensatory growth. In: LAWRENCE, T.L.J.; FOWLER, V.R. Growth of farm animals. Oxon: CAB International, 1997. p. 219-245.

LENG, R.A.; PRESTON, T.R. Sugar cane for cattle production: present contraints, perspectives and research priorites. Tropical Animal Production, v.1, p.1-22, 1976.

LUCHIARI FILHO, A. Characterization and prediction of carcass cutability traits of zebu crossbred types of cattle produced in southeast Brazil. Manhattan, 1986. 86 p. Dissertation (Doctoral) - Kansas State University.

MACHADO, M.C. Avaliação de alimentos para ruminantes pelo sistema in vitro de produção de gases e pela estimativa de síntese microbiana a partir da incorporação de radiofósforo. Piracicaba, 2001. 50 p. Dissertação (Mestrado) - Escola Superior de Agricultura "Luiz de Queiroz", Universidade de São Paulo.

MENEZES JUNIOR, M.P. Efeito do processamento do grão de milho e sua substituição parcial por polpa de citros peletizada sobre o desempenho, digestibilidade de nutrientes e parâmetros sangüíneos de vacas de leite. Piracicaba, 1999. 97 p. Dissertação (Mestrado) - Escola Superior de Agricultura "Luiz de Queiroz", Universidade de São Paulo.

MONTEPILLIER, F.A.; PRESTON, T.R. Digestibility and voluntary intake on sugar cane diets: effects of chopping the cane stalk in particles of different sizes. Tropical Animal Production, v. 2, p. 40-43, 1977.

MUIRHEAD, S. Wet corn gluten feed may reduce ruminal subacute acidosis in cattle. Feedstuffs, p.10, Dec., 1994. 
NATIONAL RESEARCH COUNCIL. Nutrient requeriments of beef cattle. 6.ed. Washington: National Academic Press, 1984. 381p.

NATIONAL RESEARCH COUNCIL. Nutrient requeriments of beef cattle. 7.ed. Washington: National Academic Press, 1996. 242p.

NATIONAL RESEARCH COUNCIL. Nutrient requeriments of dairy cattle. 6.ed. Washington: National Academic Press, 1989. 248p.

NATIONAL RESEARCH COUNCIL. Nutrient requeriments of dairy cattle. 7.ed. Washington: National Academic Press, 2001. 408p.

NOCEK, J.E. Bovine acidosis: Implications on laminitis. Journal of Dairy Science. v.80, p.1005-1028, 1997.

NOCEK, J.E.; TAMMINGA, S. Site of digestion of starch in the gastrointestinal tract of dairy cows and its effect on milk and composition. Journal of Dairy Science, v.74, p.3598, 1991.

OLIVEROS, B.A.; KLOPFENSTEIN, T.J.; GOEDEKEN, F.K. et al. Corn fiber as an energy supplement in high-roughage diets fed to steers and lambs. Journal of Animal Science, v.67, n.7, p.1784-1792, 1989.

O'MARA, F.P.; COYLE, J.E.; DRENNAN, M.J. et al. A comparison of digestibility of some concentrate feed ingredients in cattle and sheep. Animal Feed Science and Technology, v.81, p. 167-174, 1999.

ORSKOV, E.R. Starch digestion and utilization in ruminants. Journal of Animal Science, v.63, p.1624, 1986. 
OWENS, F.N.; SECRIST, D.S.; HILL, W.J. et al. A new look at acidoses. In: SOUTHWEST NUTRITION AND MANAGEMENT CONFERENCE, Phoenix, 1996. Proceendings. Phoenix: University of Arizona, 1996. p. 1-16.

OWENS, F.N.; SECRIST, D.S.; HILL, W.J. et al. The effect of grain source and grain processing on performance of feedlot cattle: a review. Journal of Animal Science. v.75, p.868-879, 1997.

PEDROSO, A.F.; SCHMIDT, P.; NUSSIO, L.G. Silagem de cana-de-açúcar no confinamento de bovinos. In: SIMPÓSIO SOBRE BOVINOCULTURA DE CORTE, 5., Piracicaba, 2004. Anais. Piracicaba: FEALQ, 2004. p. 243-259.

PERKINS, T.L.; GREEN, R.D.; HAMLIN, K.E.; SHEPARD, H.H.; MILLER, M.F. Ultrasonic prediction of carcass merit in beef cattle evaluation of technician effects on ultrasonic estimates of carcass fat thickness and longissimus muscle area. Journal of Animal Science, v.70, p.2758-2765, 1992.

PETER, C.M.; FAULKNER, D.B.; MERCHEN, N.R.; PARRETT, D.F. ; NASH, T.G.; DAHLQUIST, J.M. The effects of corn milling coproducts on growth performance and diet digestibility by beef cattle. Journal of Animal Science. v.78, p.1-6, 2000.

PIZON, F.J.; WING, J.M. Effects of citrus pulp in high urea rations for steers. Journal of Dairy Science, v. 59, p.1100, 1976.

PRADO, I.N.; PINHEIRO, A.G.; ALCALDE, C.R. et al. Níveis de substituição do milho pela polpa de citrus peletizada sobre o desempenho e características de carcaça de bovinos mestiços confinados. In: REUNIÃO ANUAL DA SOCIEDADE BRASILEIRA DE ZOOTECNIA, 37., Viçosa, 2000. Anais. Viçosa: SBZ, 2000. p.2135-2141. 
PRATES, E.R. Arroz e cereais de inverno. In: SIMPÓSIO SOBRE NUTRIÇÃO DE BOVINOS, 6., Piracicaba, 1995. Anais. Piracicaba: FEALQ, 1995. p.7398.

PRESTON, T.R.; CARCAÑO, C.; ALVAREZ, P.F. et al. Tropical Animal Production, v.1, p. 150-162, 1976.

REYNOLDS, C.K. Economics of visceral energy metabolism in ruminants: toll keeping or internal revenue service. Journal of Animal Science. v.80, suppl. 2, e.74-84, 2002.

REYNOLDS, C.K.; HARMON, D.L.; CECAVA, M.J. Absorption and delivery of nutrients for milk protein synthesis by portal-drained viscera. Journal of Dairy Science, v.77, p.2787, 1994.

REYNOLDS, C.K.; HUNTINGTON, G.B.; TYRREL, H.F. et al. Net portal-drained visceral and hepatic metabolism of glucose, L-lactate, and nitrogenous compounds in lactating holstein cows. Journal of Dairy Science, v.71, p.1803, 1988a.

REYNOLDS, C.K.; HUNTINGTON, G.B.; TYRREL, H.F. et al. Net metabolism of volatile fatty acids, D-B-hydroxybutirate, nonesterified fatty acids, and blood gases by portal-drained viscera and liver of lactating holstein cows. Journal of Dairy Science, v.71, p. 2395, 1988b.

ROONEY, L.W.; PFLUGFELDER, R.L. Factors affecting starch digestibility with special emphasis on sorghum and corn. Journal of Animal Science, v.63, p.1607, 1986. 
SAMPAIO, A.A.M.; ANDRADE, P.; OLIVEIRA, M.D.S. et al. Uso de rações com diferentes níveis de proteína e fontes de energia na alimentação de bovinos confinados. Fase II. Revista da Sociedade Brasileira de Zootecnia. v.4, n.13, p.528-533, 1984.

SANTOS, F.A.P.; HUBER, J.T.; THEURER, C.B. et al. Milk yield and composition of lactating cows fed steam-flaked sorghum and graded concentrations of ruminally degradable protein. Journal of Dairy Science, v.81, p. 215-20, 1998.

SANTOS, F.A.P.; PEREIRA, E.M.; PEDROSO, A.M. Suplementação energética de bovinos de corte em confinamento. In: SIMPÓSIO SOBRE BOVINOCULTURA DE CORTE, 5., Piracicaba, 2004. Anais. Piracicaba: FEALQ, 2004. p.261-297.

SAS INSTITUTE. SAS user's guide: statistics. Cary, 1999. 965p.

SCHALCH, F.J.; SCHALCH, E.; ZANETTI, M.A. et al. Substituição do milho grão moído pela polpa cítrica na desmama precoce de bezerros leiteiros. Revista Brasileira de Zootecnia, v.30, n.1, p.280-285, 2001.

SILVA, D.J. Análise de alimentos: métodos químicos e biológicos. Viçosa: Universidade Federal de Viçosa, 1990. 166p.

SILVEIRA, A.C. Produção do novilho precoce. In: SIMPÓSIO SOBRE BOVINOCULTURA DE CORTE, 5., Piracicaba, 2004. Anais. Piracicaba: FEALQ, 2004. p.227-241. 
SINDT, J.J.; DROUILLARD, J.S.; MONTGOMERY, S.P. et al. Combinations of wet corn gluten feed and steam flaked corn in finishing cattle diets. Cattlemen's Day, p. 48-50, 2000.

SINDT, J.J.; DROUILLARD, J.S.; TITGEMEYER,E.C. et al. Steam-flaked corn diets containig combinations of wet corn gluten feed and alfafa hay: effects on diet digestibility and ruminal characteristics. Cattlemen's Day, p. 30-32, 2002.

SNIFFEN, C.J. Balancing rations for carbohydrates for dairy cattle. In: Proceedings of the 1988 Feed Dealer Seminars, Cornell Cooperative Extension, n.112, p.9-19, 1988.

SNIFFEN, C.J.; O'CONNOR, J.D.; VAN SOEST, P.J. et al. A net carbohydrates and protein system for evaluating cattle diets: II. Carbohydrate and protein availability. Journal of Animal Science, v.70, p.3552-3577, 1992.

STAPLES, C.R.; DAVIS, C.L.; Mc COY, G.C. et al. Feeding value of wet corn gluten feed for lactating dairy cows. Journal of Dairy Science, v.67, p.1214, 1984.

STERN, M. D.; ZIEMER C. J. Consider value, cost when selecting nonforage fiber. Feedstuffs, v.17, p.14, Jan. 1993.

THEURER, C.B. Grain processing effects on starch utilization by ruminants. Journal of Animal Science, v.63, p.1649, 1986.

THEURER, C.B. Steam-flaked grain for high producing dairy cows. In: SOUTHWEST NUTRITION AND MANAGEMENT CONFERENCE, Scottsdale, 1992. Proceedings. Scottsdale: Univ. Arizona, 1992. p.64. 
THEURER, C.B.; LOZANO, O.; ALIO, A. et al. Steam-processed corn and sorghum grain flaked at different densities alter ruminal, small intestinal, and total tract digestibility of starch by steers. Journal of Animal Science, v.77, p.2824-2831, 1999.

TRENKLE, A.H. Use of wet corn gluten feed in no roughage diets for finishing cattle. Ames: Iowa State University Animal Science, 1987. 65p. (Leaflet, R442).

TULLIO, R.R. Estratégias de manejo para a produção intensiva de bovinos visando a qualidade da carne. Jaboticabal, 2004. 39 p. Tese (Doutorado) Faculdade de Ciências Agrárias e Veterinárias, Universidade Estadual Paulista "Júlio de Mesquita Filho".

VAN SOEST, P.J. Nutritional ecology of ruminant. Ithaca: Comstock Publishing Associations, 1994. 476p.

VAN SOEST, P.J.; ROBERTSON, J.B.; LEWIS, B.A. Methods for dietary fiber, neutral detergent fiber, and nonstarch polysaccharides in relation to animal nutrition. Journal of Dairy Science, v.74, p.3583-96, 1991.

VIJCHUAlTA, P., HENRY, P.R., AMMERMAN, C.B. et al. Effect of dried citrus pulp and cage layer manure in combination with monensin on performance and tissue mineral composition in finishing steers. Journal of Animal Science. v.50, n.6, p.1022-1030, 1980.

WEISS, W.P.; CONRAD, H.R.; PIERRE, R.S. A theoretically-base model for predicting total digestible nutrient values of forages and concentrates. Animal Feed Science and Technology, v.39, p.95-119, 1992. 
WING, J.M. Citrus feedstuffs for dairy cattle. Gainesville: University of Florida, Agricultural Experiment Stations, 1982. 25p. (Bulletin, 829).

YOKOYAMA, M.T.; JOHNSON, K.A. Microbiology of the rúmen and intestine. In: $\mathrm{CHURCH}$, D.C. (Ed). The ruminant animal digestive physiology and nutrition. Englewood Cliffs: Prentice Hall, 1988. p.125-144.

YU,P.; HUBER, J.T.; SANTOS, F.A.P. et al. Effects of ground, steam-flaked, and steam-rolled corn grains on performance of lactating cows. Journal of Dairy Science, v.81, p.777-783, 1998.

ZINN, R.A. Reevaluation of urea in feedlot diets. In: SOUTHWEST NUTRITION AND MANAGEMENT CONFERENCE, Phoenix, 1994. Proceedings. Phoenix: University of Arizona, 1994. p.17.

ZINN, R.A.; SHEN, Y. An evaluation of ruminally degradable intake protein and metabolizable amino acid requirements of feedlot calves. Journal of Animal Science, v.76, p.1280-1289, 1998.

ZINN, R.A.; OWENS, F.N.; WARE, R.A. Flaking corn: processing mechanics, quality standards, and impacts on energy availability and performance of feedlot cattle. Journal of Animal Science, v.80, p.1145-1156, 2002. 
APÊNDICES 


\section{APÊNDICE 1}

Resultados da formulação da ração do Experimento 1 tratamento MP do modelo do NRC (1996) nível 1:

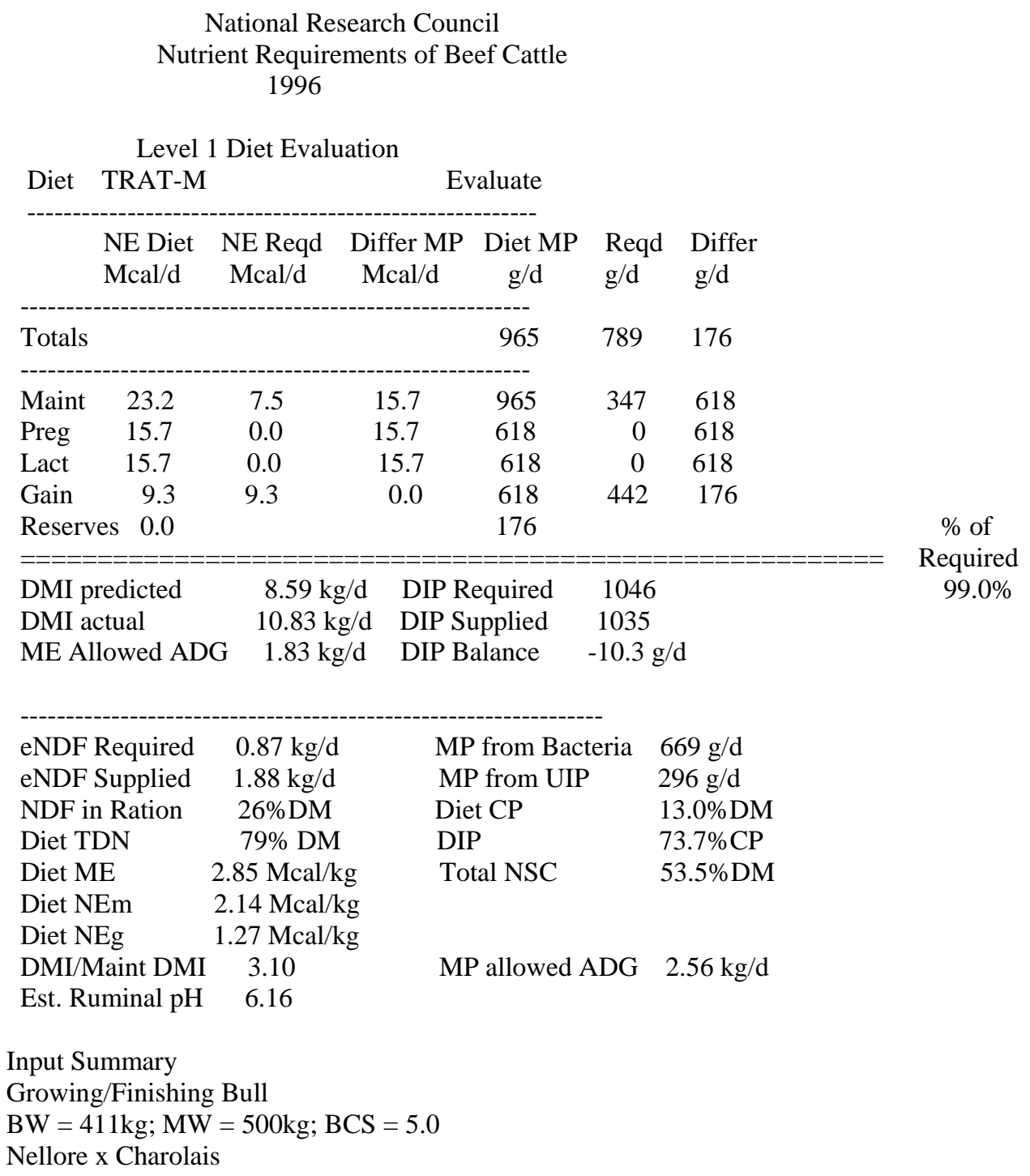




\section{APÊNDICE 2}

Resultados da formulação da ração do Experimento 1 tratamento P50 do modelo do NRC (1996) nível 1:

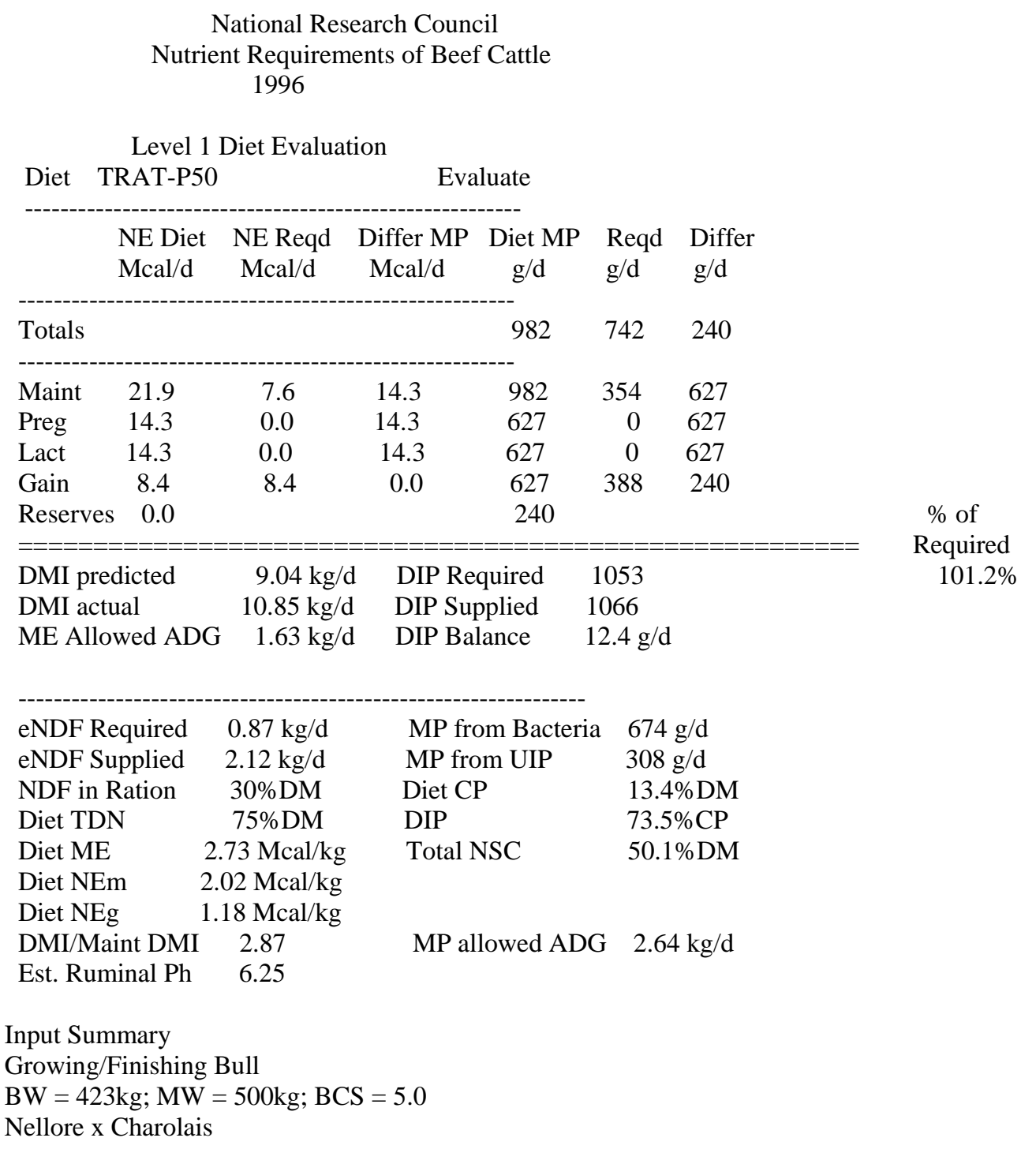




\section{APÊNDICE 3}

Resultados da formulação da ração do Experimento 1 tratamento P75 do modelo do NRC (1996) nível 1:

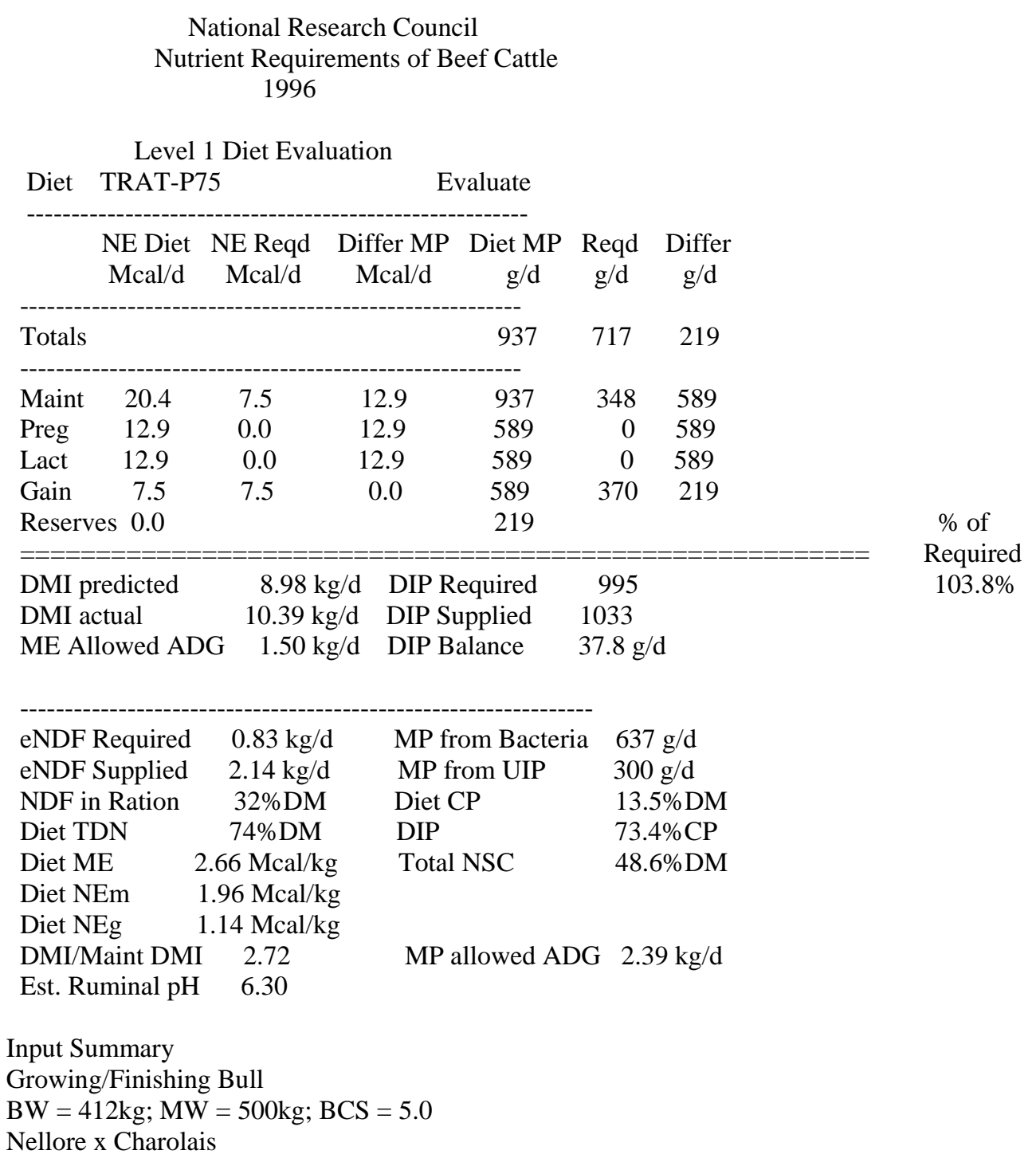




\section{APÊNDICE 4}

Resultados da formulação da ração do Experimento 1 tratamento $P$ do modelo do NRC (1996) nível 1:

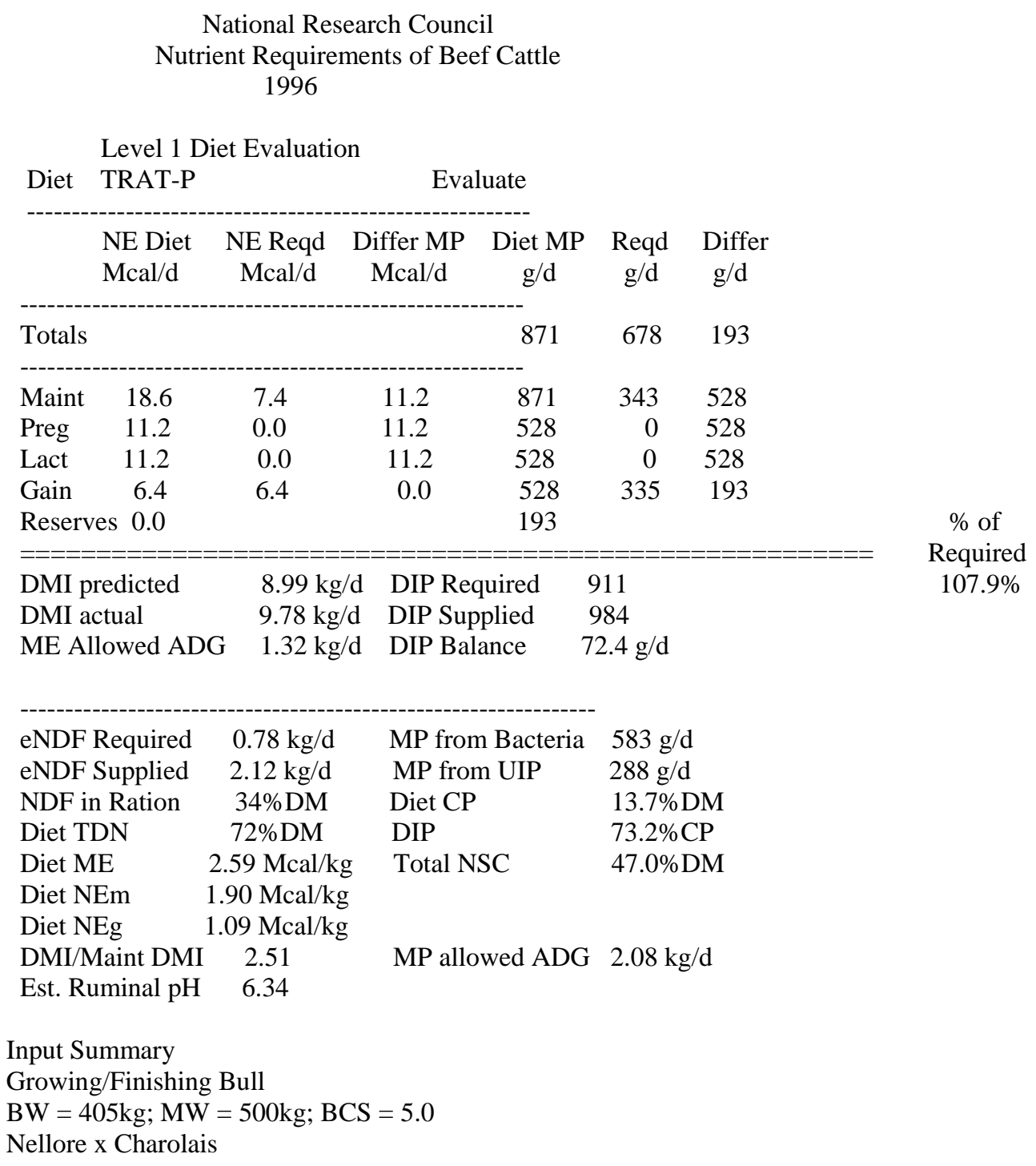




\section{APÊNDICE 5}

\section{Resultados da formulação da ração do Experimento 2 tratamento MP do modelo do NRC (1996) nível 1:}

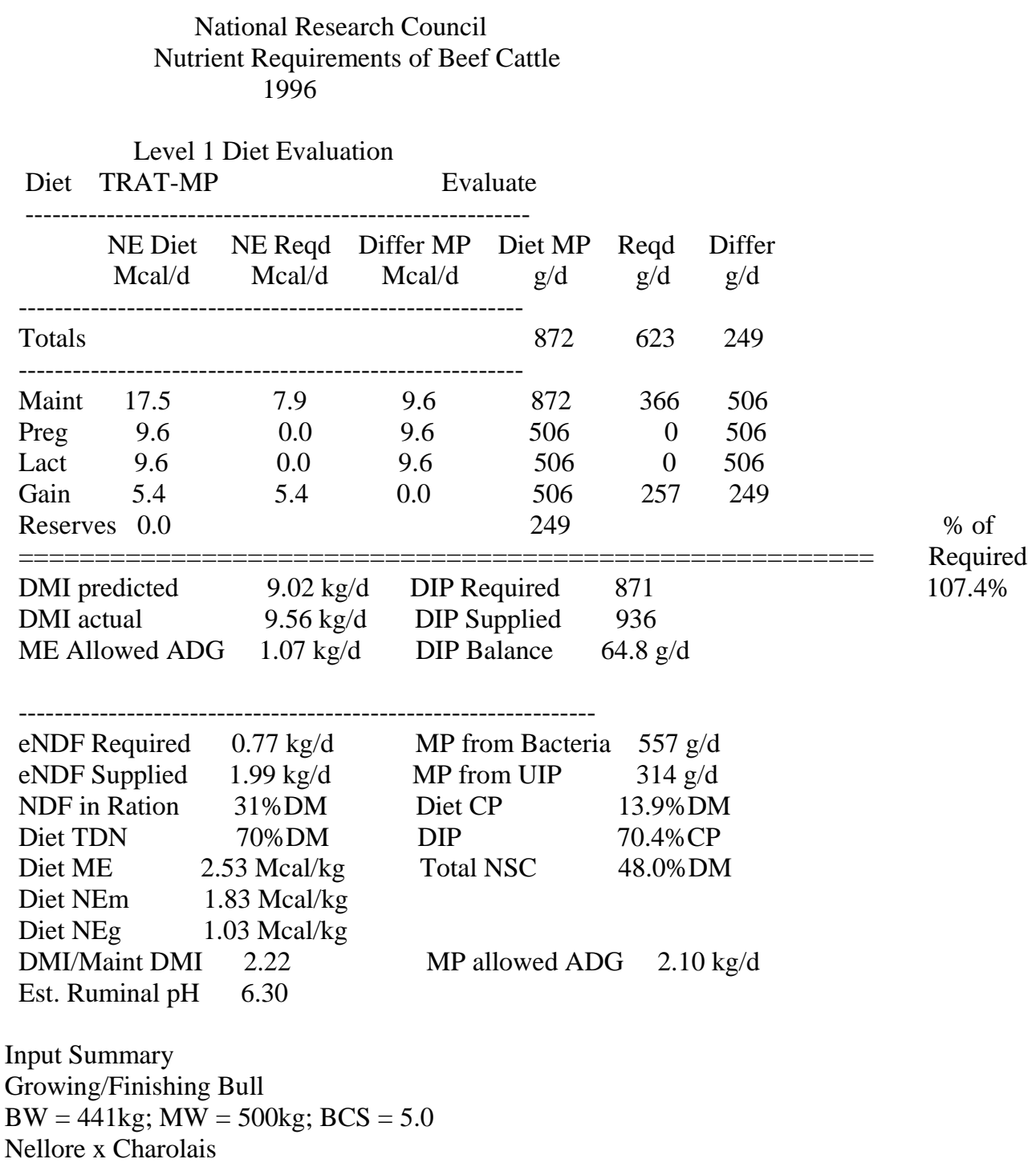




\section{APÊNDICE 6}

Resultados da formulação da ração do Experimento 2 tratamento FTP do modelo do NRC (1996) nível 1:

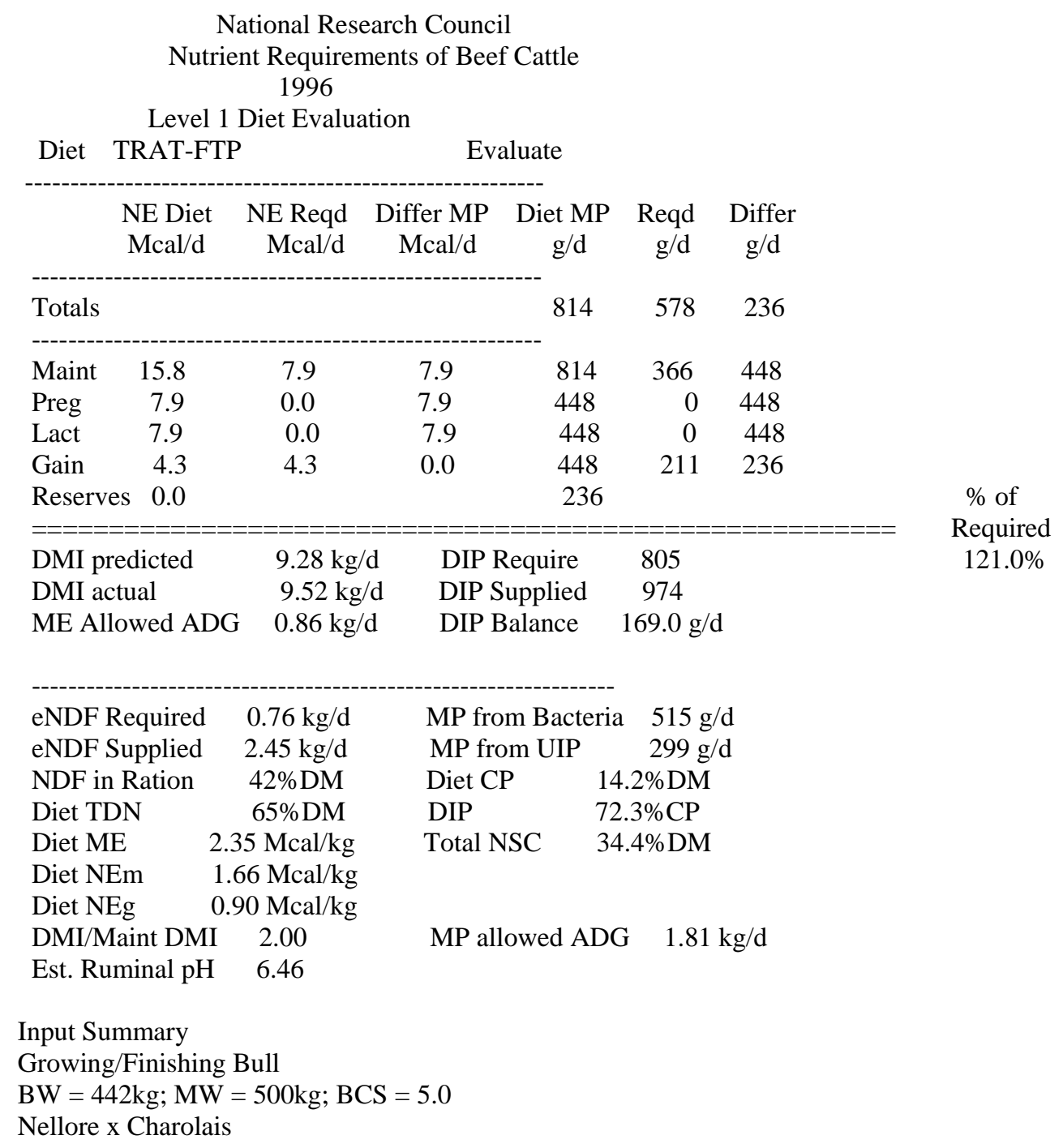




\section{APÊNDICE 7}

Resultados da formulação da ração do Experimento 2 tratamento FGP do modelo do NRC (1996) nível 1:

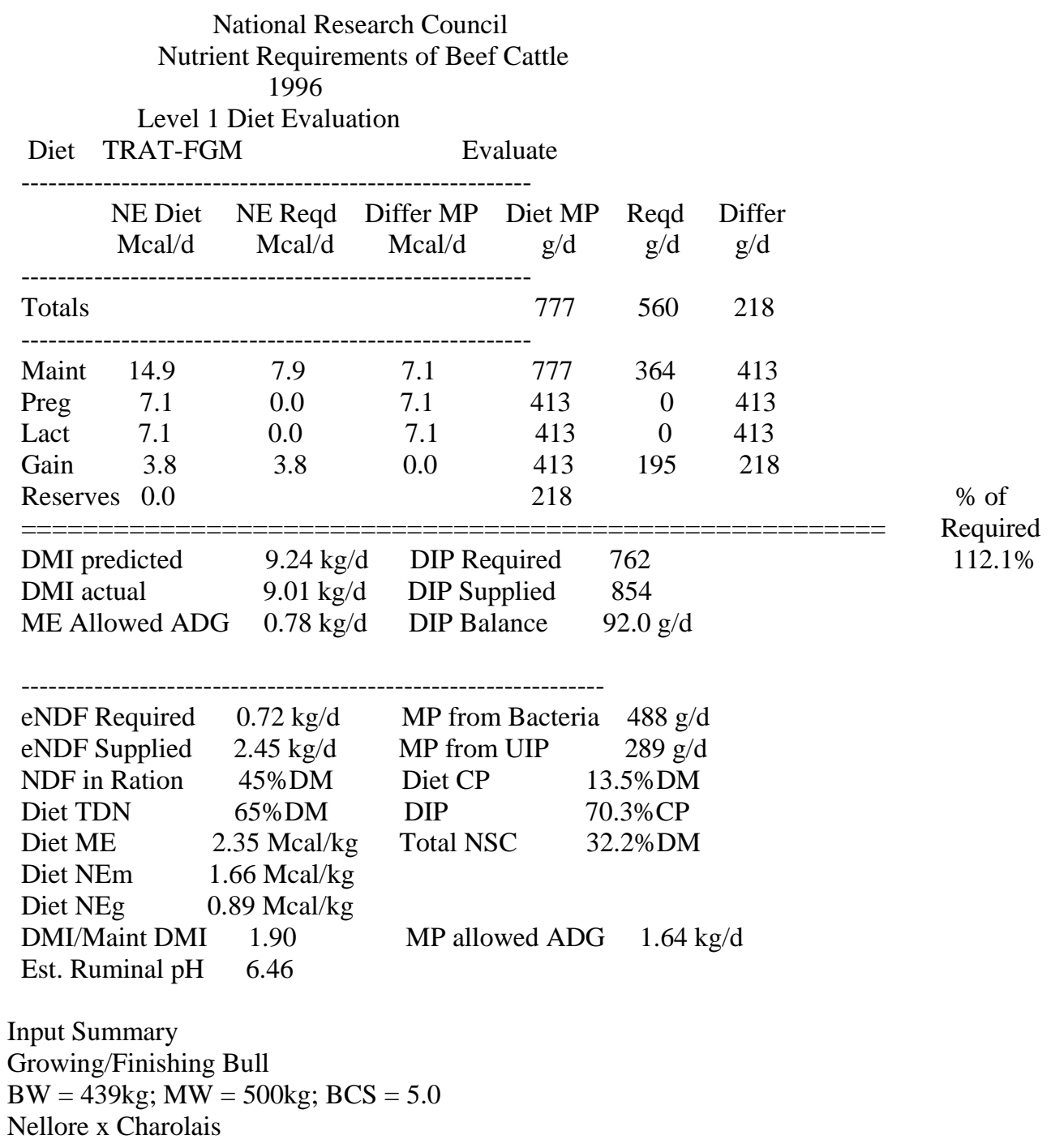

